\title{
Geochemical Appraisal of Chemical Weathering and Metal Contamination in Coastal Surface Sediments, Off Northwest Hainan Island, the Gulf of Tonkin
}

\author{
Dawei Liu', Baozhi Lin', Selvaraj Kandasamy ${ }^{1,2 *}$, Huawei Wang ${ }^{1}$, Qianqian Liu', \\ Wenbin Zou ${ }^{1}$, Aimei Zhu ${ }^{3}$, Jianjun Zou ${ }^{3}$, Jiann-Yuh Lou ${ }^{4}$ and Xuefa Shi ${ }^{3}$
}

${ }^{1}$ Department of Geological Oceanography and State Key Laboratory of Marine Environmental Science, College of Ocean and Earth Sciences, Xiamen University, Xiamen, China, ${ }^{2}$ Laboratory for Marine Geology, Qingdao National Laboratory for Marine Science and Technology, Qingdao, China, ${ }^{3}$ Key Laboratory of Marine Sedimentology and Environmental Geology, First Institute of Oceanography, State Oceanic Administration, Qingdao, China, ${ }^{4}$ Department of Marine Science, Republic of China Naval Academy, Kaohsiung City, Taiwan

OPEN ACCESS

Edited by:

Rathinam Arthur James, Bharathidasan University, India

Reviewed by: Chidambaram Sabarathinam,

Kuwait Institute for Scientific Research, Kuwait Prasanna Mohan Viswanathan,

Curtin University, Malaysia

*Correspondence: Selvaraj Kandasamy

selvaraj@xmu.edu.cn;

kselva8@yahoo.com orcid.org/0000-0003-2916-5055

Specialty section:

This article was submitted to Marine Pollution

a section of the journal Frontiers in Marine Science

Received: 07 March 2019 Accepted: 12 June 2019 Published: 03 July 2019

Citation:

Liu D, Lin B, Kandasamy S, Wang H, Liu Q, Zou W, Zhu A, Zou J, Lou J-Y and Shi X (2019) Geochemical Appraisal of Chemical Weathering and Metal Contamination in Coastal Surface Sediments, Off Northwest Hainan Island, the Gulf of Tonkin. Front. Mar. Sci. 6:363. doi: 10.3389/fmars.2019.00363
Coastal sediments not only contain a majority of trace metals, but they also act as a source of dissolved metal ions to the overlying water column. Distinguishing the level of trace metal enrichment from the natural input in sediments is therefore important to determine the distribution and sources of land-derived detritus and pollutants in the coastal region. This study investigates fine $(<63 \mu \mathrm{m})$ and bulk $(<230 \mu \mathrm{m})$ fractions of surface sediments from the northwest coast of Hainan Island, South China, for sedimentological and geochemical parameters to evaluate the chemical weathering conditions of source rocks and geochemical processes controlling their distribution. Among seventeen major and trace elements investigated in this study, six elements (Al, Fe, Cr, Ni, V, and Zn) varied spatially. Among four transects investigated, bulk and fine sediments from three northern transects (A, B, and $C$ ) behave spatially almost similar, but the sediments from the southernmost transect (D) are characteristically different with higher contents of trace elements because of direct riverine influence with heavy mineral dominance. Range and mean values of weathering indexes, chemical index of alteration (CIA; 59-79 and 73) and chemical index of weathering (CIW; 78-91 and 85 ) as well as triangular plots of silicate weathering, revealed that sediments were derived from both granitic and basaltic rocks that have undergone moderate chemical weathering processes in the provenance. Normalization of trace elements to Al and the enrichment factor (EF) for fine and bulk sediments showed higher mean EF (>2) for $\mathrm{As}, \mathrm{Cd}$, and $\mathrm{Pb}$, suggesting that the sediments were likely enriched by these elements. A comparative study of trace metals concentrations and EF with other coastal regions of China, however, revealed that the study area is in a pristine environmental condition compared to other coastal regions of eastern China. Factor analysis identified three dominant sedimentological and geochemical associations, accounting for $\sim 70 \%$ of total variance, recognize terrigenous input, heavy mineral role and anthropogenic input in controlling the distribution of most elements in the study area.

Keywords: geochemistry, weathering, metal contamination, provenance, sediments, the Gulf of Tonkin 


\section{INTRODUCTION}

Sediments are the major product of chemical and physical weathering that largely exported to the ocean marginal depocenters such as estuaries and coastal regions by rivers roughly on daily to seasonal basis (Milliman and Syvitski, 1992; Meybeck et al., 2003; Syvitski and Milliman, 2007). Geochemically, these sediments are a mixture of inorganic and organic material, consisting dominantly of solid particulate matter (detritus) or have been incorporated into the sediments from solution (non-detrital) in a number of pathways, but a combination of varying proportions of both in general (Loring, 1991; Loring and Rantala, 1992; Selvaraj et al., 2004, 2010). The geochemical composition of sediments is therefore largely governed by the characteristics of their origin and physicochemical characteristics of the depositional environment and associated natural biogeochemical processes such as diagenesis, adsorption onto/desorption from organic matter, and precipitation-dissolution of $\mathrm{Fe}-\mathrm{Mn}$ oxyhydroxides (e.g., Berner, 1980). Nevertheless, since the 1950s, owing to frequent waste discharges from modern industrial, agricultural, and domestic activities (Nriagu and Pacyna, 1988; Grimalt et al., 2001), the geochemical composition of estuarine and coastal sediments have been significantly affected by trace metals "contamination" as the sediments are main carriers of trace elements in the aquatic system (Salomons and Förstner, 1980). Industrial effluents and human wastes contain a variety of trace metals and their discharges are considered as huge (Szefer et al., 1995; Rainbow, 2007), in particular tropical and subtropical regions of Asia, where the population density is the highest with mega-industrial set-up.

Distinguishing anthropogenic contribution from that of natural sources on elemental concentration in sediments is vital (Loring and Rantala, 1992; Selvaraj et al., 2010). For that reason, sedimentary geochemical composition is viewed as essential for environmental monitoring and ecosystem assessment programs because they are very sensitive and reliable recorders of both natural and anthropogenic sources of elements at fairly detectable levels (Förstner and Wittmann, 1981; Szefer, 2002). Thus geochemical characteristics of the sediments and sedimentary rocks can be used to infer the weathering trends and the sources of pollution (Fedo et al., 1996; Nesbitt et al., 1996; Nath et al., 2000; Selvaraj et al., 2004; Armstrong-Altrin and MachianCastillo, 2016). A number of previous studies on the spatial and temporal geochemical records of sediments have delineated recent contamination levels and pollution histories within the estuarine, coastal and shelf regions worldwide (Szefer et al., 1995; Zwolsman et al., 1996; Nolting et al., 1999; Selvaraj et al., 2004, 2010). Given the due consideration of the developing phase of many Asian countries, the critical metal contamination studies of estuarine and coastal regions are rather very limited. Previous studies have investigated major and trace metals in sediments along the coastal and estuarine regions of China, but these studies in general lack of critical evaluation, as many of them have rarely been attempted to differentiate the trace metal content that is associated with aluminosilicates from that of one is sourced from modern activities (e.g., Bastami et al., 2012; Pan and Wang, 2012;
Gan et al., 2013), probably due to lack of geochemical knowledge on chemcial weathering of source rocks and sediment genesis. For instance, a critical evaluation of major and trace elemental characteristics of surface and core sediments from the offshore of southwestern Taiwan revealed that sediments were contaminated by few metals due to a non-point source and related biogeochemical changes (Chen and Selvaraj, 2008; Selvaraj et al., 2010).

The Gulf of Tonkin (GOT; also called as Beibu Gulf or Beibu Bay) is a marginal sea of the South China Sea (Figure 1A), playing a key role for the understanding of naturally sourced and anthropogenically induced matter and energy fluxes in the northwestern coastal regions of South China Sea. Recent developments in the western part of the Hainan Island likely drive the gulf as one of the potential areas of future contamination that may alter the sedimentary regime and increase environmental deterioration of the shallow coastal region. Hence, a complete geochemical evaluation of major and trace elemental sources and geochemical processes regulating them need to be addressed. The GOT is also one of the less investigated marginal environments in the South China Sea (e.g., Gao et al., 2017; Figure 1A). A study conducted through the German/Chinese bilateral research has focused on the investigation of hydrographic, sedimentological and geochemical parameters in the GOT (Bauer et al., 2013). They demonstrated that hydrographic parameters not only influence the water column biogeochemistry, but also affect the biogeochemical characteristics of sediments. They also noted accumulation of fine sediments sourced from the South China Sea, as well as Pearl River, through the Qiongzhou Strait due to strong tide-induced currents (Figure 1A). The intensity of river discharges and the transport through Qiongzhou Strait to the gulf are largely controlled by the monsoon strength (Tanabe et al., 2003; Xu et al., 2008). As typhoon-induced rainfall shares $\sim 30 \%$ of total annual precipitation $(\sim 1750 \mathrm{~mm})$ over Hainan Island (Wu et al., 2007), both physical erosion and chemical weathering of source rocks can account for a larger portion of sediment sources to the coastal region (Song, 2009; Xia et al., 2012). In addition to the weathered material, industrial emission and sanitary sewage carried during rainfall are delivered to the coastal zone in the eastern part of the GOT, where concentrations of $\mathrm{As}, \mathrm{Cr}$, and $\mathrm{Hg}$ were reported to be higher than that of these elements in the open sea (Jin et al., 2011).

Compared to the northern and western parts of the GOT, there is no mega-industrial set-up or dense population centers along the coastal regions of eastern GOT, but aquaculture thrives, implying that the contamination state of sea bed could be better than the northern and western coastal areas of GOT. Nevertheless, surface sediments of coastal regions $(<50 \mathrm{~m}$ water depths) in the eastern Gulf along the northwest coast of Hainan Island, South China, have never been investigated geochemically, hampering our understanding of geochemical composition of Island-derived sediments and the processes controlling their distribution, including trace metal contamination levels. Here we therefore investigate seventeen major and trace elemental (Al, As, Ca, Cd, Cr, Cu, Fe, K, Mg, Mn, Na, Ni, P, Pb, Ti, $\mathrm{V}$, and $\mathrm{Zn}$ ) concentrations in surface sediments, along with total organic carbon (TOC) and calcium carbonate $\left(\mathrm{CaCO}_{3}\right)$ 

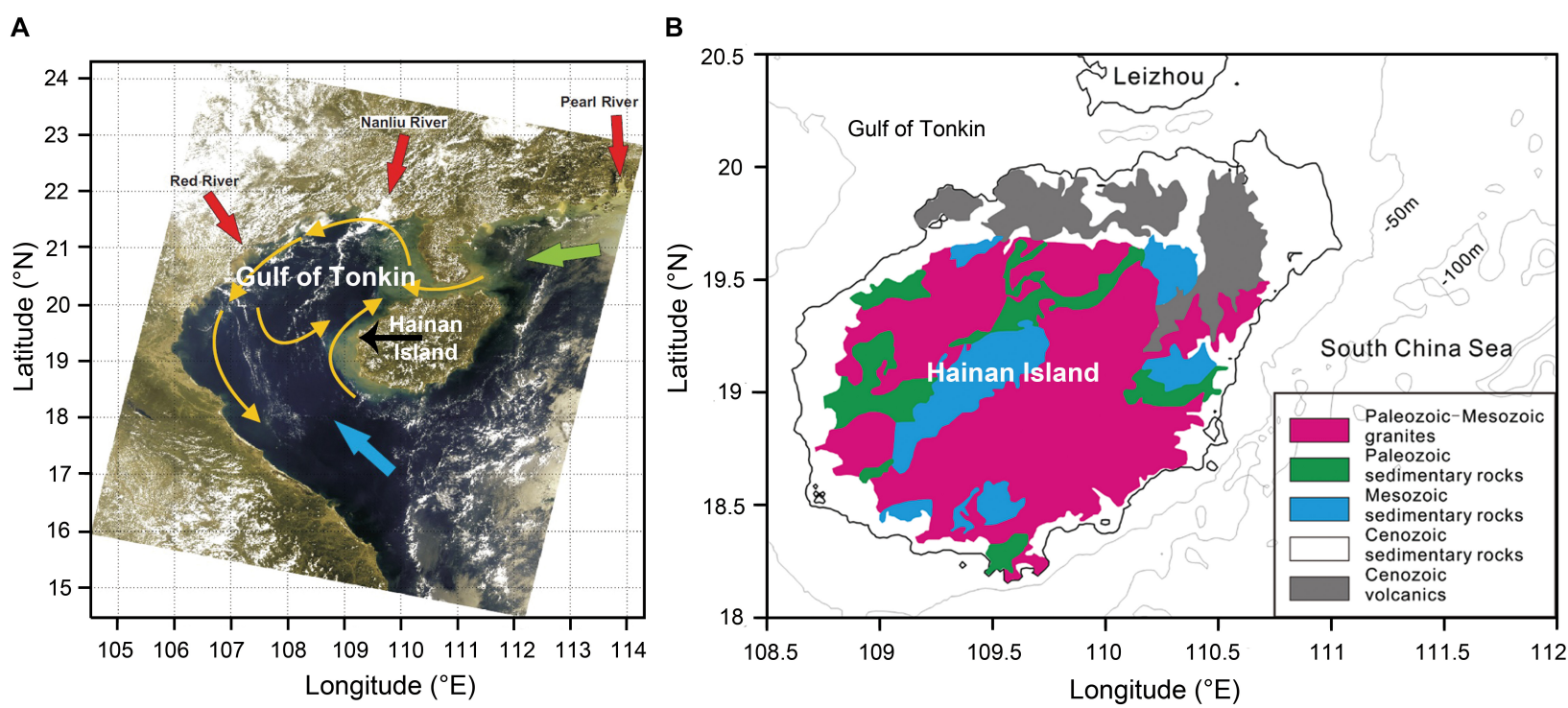

FIGURE 1 | (A) Satellite image of the Gulf of Tonkin from ESA ENVISAT MERIS, showing the general circulation patterns (yellow arrows) and material inputs (riverine: red arrows; coast parallel: green arrow; and marine: blue arrow). Black arrow on the Hainan Island represents riverine input from the island to the Gulf of Tonkin [modified from Bauer et al. (2013)]. (B) A simplified map of Hainan Island showing major geological formations in the island [modified from Shi et al. (2011), Zhao et al. (2015)]. See text for more details.

contents, from this region aiming (i) to understand the chemical weathering conditions of source rocks; (ii) to evaluate the metal contamination status of the study area; and (iii) to compare the metal contamination results obtained in this study with the published results from other coastal regions of China. To achieve these objectives, we calculated chemical weathering indices and applied methods of elemental normalization and statistical techniques to the geochemical data of coastal surface sediments in the study area.

\section{STUDY AREA}

Hainan Island is located on the northern fringe of the tropical zone in the northern part of the South China Sea (Figure 1B). It is a continental-type island and also the largest tropical island of South China, with a surface area of $35.4 \times 10^{3} \mathrm{~km}^{2}$ (Hu et al., 2014; Jiang et al., 2018). Hainan Island contains diverse rocks with a range of ages (Figure 1B). Although the island is dominated by Paleozoic-Mesozoic granitic rocks, which account for $\sim 40 \%$ of the island's land area, Cenozoic basalts are distributed widely in the northern part of island (Hu et al., 2014). While Late Paleozoic to Mesozoic granitoids and Cenozoic basalts are dominantly exposed on the island, Proterozoic, Paleozoic, Mesozoic and Cenozoic rocks occur as isolated outcrops ( $\mathrm{Hu}$ et al., 2014; Xu et al., 2014). Most granitoids are exposed in the central and southern parts of Hainan Island, and basalts are distributed in the northern part of the island (Figure 1B). Paleozoic-Mesozoic sedimentary rocks are widely developed in the west and scattered in the east Hainan Island. Paleozoic sedimentary rocks are shallowmarine strata, consisting of sandstone, slate and limestone, while
Mesozoic sedimentary rocks are terrestrial strata, dominating by volcanic-clastic rocks. Additionally, Quaternary sediments are widely distributed in the coastal plain around Hainan Island (Figure 1B). The annual mean temperature ranges from 22.8 to $25.8^{\circ} \mathrm{C}$ and the annual mean rainfall varies between $\sim 960$ and $2150 \mathrm{~mm}$, with lower rainfall in the rain shadow western part of the island.

Owing to East Asian monsoon climate, rivers traversing Hainan Island discharge approximately $14 \times 10^{10} \mathrm{~m}^{3}$ annually into the South China Sea, of which $3 \times 10^{10} \mathrm{~m}^{3}$ occurs during summer season (May-October), when tropical storms (typhoons) hit the island frequently (Yang et al., 2013; Zhang et al., 2013). Bauer et al. (2013) suggested that the coastal region of the gulf may receive material mainly from rivers entering the GOT at the north coast or along the west coast of Hainan Island. River loads from the Red River and smaller rivers in the northern coastal area (Tang et al., 2003) are transported southward through the GOT interacts with the surrounding South China Sea through water mass exchanges (Wu et al., 2008). The sediments that delivered from the Pearl River located $\sim 400 \mathrm{~km}$ away to the northeast may also reach the gulf through the Qiongzhou Strait (Tang et al., 2003). Rivers on the Hainan Island delivered about 4 million tons of sediments into the South China Sea annually, in which the three largest rivers - Nandu, Changhua, and Wanquan - contribute ca. 0.84, 0.52, and 0.52 million tons, respectively ( $\mathrm{Li}, 1992)$.

The GOT is a shallow, crescent-shaped, subtropical basin with an area of $12.93 \times 10^{4} \mathrm{~km}^{2}$ and situated in the northwest of South China Sea (Figure 1B). It is surrounded by Leizhou Peninsula, Hainan Island, Guangxi Province, and Vietnam (Figures 1, 2). The mean water depth of the GOT is $\sim 42 \mathrm{~m}$ with the deepest part goes down to $\sim 100 \mathrm{~m}$. Wind, tidal currents and currents outside 


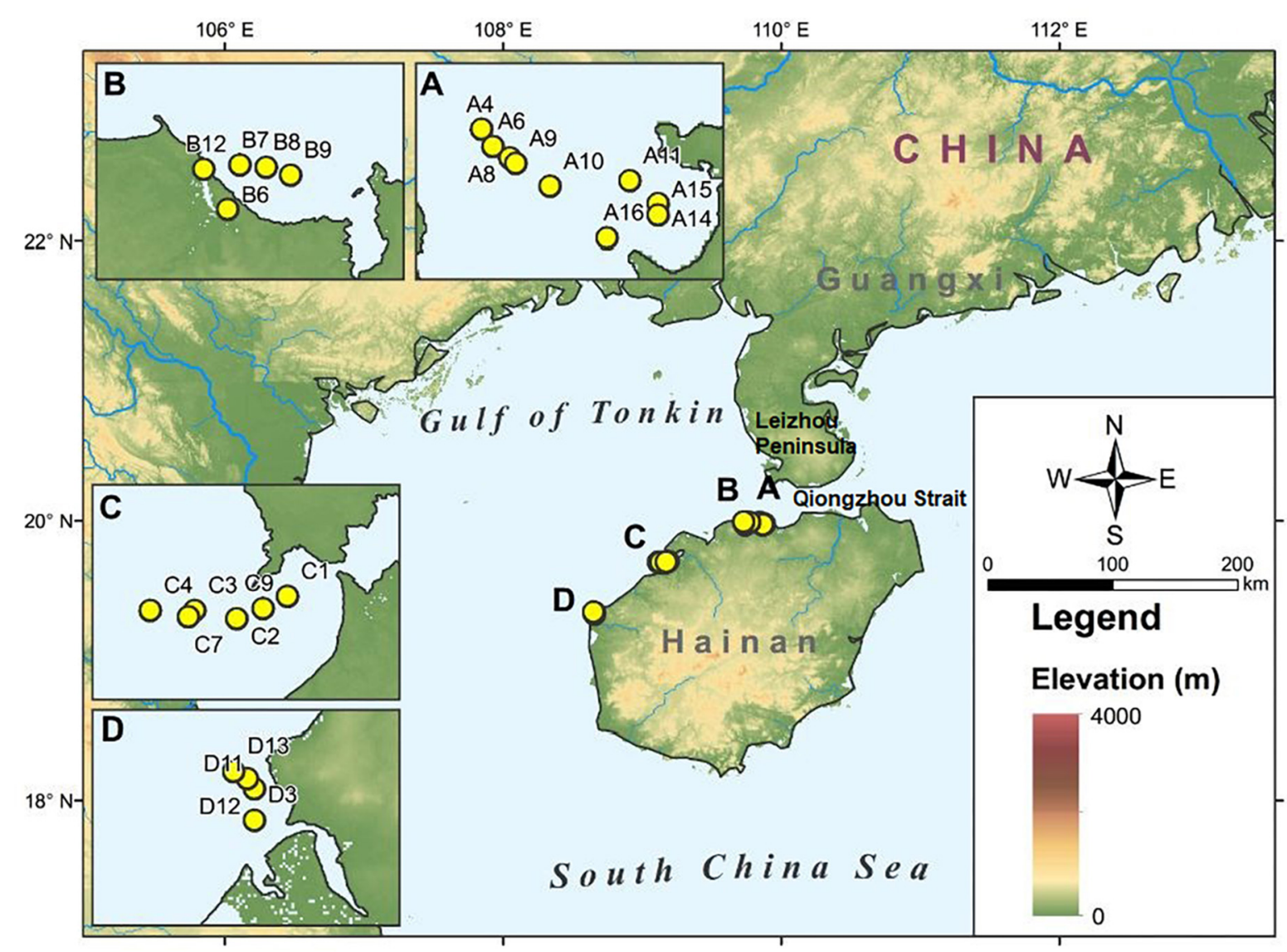

FIGURE 2 | Map of Gulf of Tonkin showing locations of surface sediments collected for the geochemical study. Samples were collected along four transects, namely Chengmai (A), Lingao (B), Baimajing (C), and Changhua (D). Also shown are enlarged views of these transects and surface sediments locations with sample numbers.

the gulf largely regulate the circulation in the Gulf (Chen et al., 2009). The surface circulation reverses from a winter cyclonic to a summer anticyclonic due to change from NE to SW monsoon winds (Manh and Yanagi, 1997, 2000). Wu et al. (2008) argued that despite the surface wind stress is monsoonal - southwesterly in the summer and northeasterly in the winter - the circulation is cyclonic in all seasons in the gulf. The tide-induced westward mean transport of $\sim 0.1-0.2 \mathrm{~Sv}$ through Qiongzhou Strait into the GOT thought to be a key factor for the cyclonic circulation in the summer as well as for other seasons (Shi et al., 2002; Cai et al., 2003). The marine influence from the south is mainly driven by tidal waves propagating into the gulf through the wide opening with a current velocity of $\sim 40 \mathrm{~cm} \mathrm{~s}^{-1}$ (Manh and Yanagi, 1997). The measurement of full tidal cycle $(25 \mathrm{~h})$ at one station in the gulf revealed a southeasterly directed mean water movement of 22.8 and $26.8 \mathrm{~km} \mathrm{~d}^{-1}$ at the surface and at $50 \mathrm{~m}$ depth, respectively. Sea bed sediment distribution is complex and is strongly influenced by current changes due to seasonal monsoons (summer and winter) and varying sources of terrigenous clastic (Coleman, 1969). The depositional center of the gulf and local depressions are largely filled with fine-grained sediments, but sandy deposits mostly seen in the shallow coastal regions (Su and Wang, 1994). A recent study has identified through zircon age spectrum that sand derived from the western and southern Hainan Island is characterized a strong $\sim 100 \mathrm{Ma}$ peak (Fyhn et al., 2019). The present investigation focuses on the northwest coastal region of Hainan Island, from Chengmai Town to Changhua River (Figure 2).

\section{MATERIALS AND METHODS}

\section{Sampling}

During November 2013, twenty-five surface sediments were collected with a Petersen stainless steel grab sampler $(15 \times 25 \mathrm{~cm}$ inner diameter) using local fishing vessels across the northwest coast of Hainan Island along four transects, A through D (namely Chengmai, Lingao, Baimajing, and Changhua; Figure 2). Water depth in the present study area is shallow with the deepest sampling site is $<20 \mathrm{~m}$. Sediment samples from the top $5 \mathrm{~cm}$ were carefully scooped from the grab sampler, placed in polyethylene 
bags and stored in ice-box below $4^{\circ} \mathrm{C}$ onboard and then transported to State Key Laboratory of Marine Environmental Science, Xiamen University. The number of samples collected in each transect depends on the nature of bottom sediments and the speed of underwater currents, given that we failed to grab samples in some stations either of these two reasons. However, at least four representative samples were collected in each transect with a maximum of nine samples along transect A. Coastal aquaculture is the major economic activity in the area, especially in transects $\mathrm{A}$ and $\mathrm{B}$, whereas building factories seen adjoining the transect $\mathrm{C}$ due to the development of aquaculture along the coastal regions. A big wharf is located on the bay of transect D (Figure 2).

\section{Geochemical Analysis}

Each freeze-dried sample was homogenized by removing particles of $>2 \mathrm{~mm}$ and then separated into fine $(<63 \mu \mathrm{m})$ and bulk sediments $(<230 \mu \mathrm{m})$ using appropriate sieves. Grain size analysis of $<2 \mathrm{~mm}$ fraction of each sediment was carried out with a Coulter LS-100 laser particle size analyzer, as detailed in Janitzky (1986). Briefly, samples were treated with $\mathrm{HCl}$ and $\mathrm{H}_{2} \mathrm{O}_{2}$ to remove carbonate and organic matter, respectively. In the final stage, sodium hexametaphosphate was added to prevent the flocculation of clay minerals and the samples received a short period of ultrasonic agitation before the measurement (Selvaraj et al., 2016).

For the TOC measurement, $\sim 1 \mathrm{~g}$ finely grounded sediment was transferred to $50 \mathrm{ml}$ centrifuge tube and about $20 \mathrm{ml}$ of $1 \mathrm{~N}$ $\mathrm{HCl}$ was added to convert inorganic carbon into carbon dioxide. After $16 \mathrm{~h}$, decarbonated samples were centrifuged at $4500 \mathrm{r} / \mathrm{min}$ for $20 \mathrm{~min}$ and dried at $50^{\circ} \mathrm{C}$ for $\mathrm{HCl}$ evaporation after decanting the supernatant and then the samples were measured for TOC with Elemental Analyzer (ANCA-GSL; Europa Scientific, Crewe, United Kingdom). Calcium carbonate $\left(\mathrm{CaCO}_{3}\right)$ content was determined by titration using the procedure detailed in Loring and Rantala (1992).

For major and trace elemental analyses, each powdered sediment sample was oven-dried at $105^{\circ} \mathrm{C}$ for $3 \mathrm{~h} .50 \mathrm{mg}$ of each aliquot transferred into the Teflon beakers was digested with ultrapure $\mathrm{HF}$ and $\mathrm{HNO}_{3}$, as detailed in Zou et al. (2012). Selected major (Al, Ca, Fe, Mg, Na, K, and $\mathrm{Ti}$ ), minor $(\mathrm{Mn}$ and $\mathrm{P})$, and trace $(\mathrm{Cr}, \mathrm{Cu}, \mathrm{Ni}, \mathrm{Pb}, \mathrm{V}$, and $\mathrm{Zn}$ ) elements were determined by Inductively Coupled PlasmaOptical Emission Spectrometry (ICP-OES; Thermo Scientific iCAP 6000). In addition, specific trace elements, such as arsenic (As) and cadmium (Cd), that are also associated with modern anthropogenic sources, were analyzed with Inductively Coupled Plasma-Mass Spectrometry (ICP-MS; Thermo Scientific XSERIES 2). Precision for most elements at the concentrations present in the reference material GSD-9 is less than 5\% relative standard deviation. All sedimentological and geochemical data of the present study are listed in Supplementary Table $\mathbf{1}$.

\section{RESULTS}

The surface sediments investigated here are mainly composed of sand and silt. Sand content ranged from 49 to $89 \%$ with a mean of $65 \%$, whereas silt content varied between 9 and $47 \%$ with a mean of $32 \%$. Clay content is very low (2-4\%). Mud content $(<63 \mu \mathrm{m})$ varied from 11 to $51 \%$ with a mean content of $35 \%$, indicating the dominance of silt-sized (4-63 $\mu \mathrm{m})$ material in the fine fraction of most sediments. TOC and $\mathrm{CaCO}_{3}$ contents in general play opposite roles, as the former adsorbs but the latter dilutes, on the concentration and distribution of many trace metals in sediments (Loring and Rantala, 1992). TOC content in surface sediments varied from 0.04 to $1.28 \%$ with a mean TOC of $0.73 \%$, whereas $\mathrm{CaCO}_{3}$ ranged from 0.33 to $25.4 \%$ with a mean of $7.9 \%$. $\mathrm{CaCO}_{3}$ contents of most samples were $<13 \%$, except four samples (A16, B12, C4, and D11; Figure 1) with $>13 \%$, suggesting the overall dominance of detrital elements in these sediments without any significant relationship among these three variables, i.e., grain size, TOC and $\mathrm{CaCO}_{3}$. Higher contents of $\mathrm{CaCO}_{3}$ in these samples seem to be attributed either to the dominance of marine productivity (C4 and D11; Figure 2) or the influence of aquaculture activity (A16 and B12; Figure 2).

The range and standard deviation (SD) of all major oxides and trace elements are (Supplementary Table 1): $\mathrm{TiO}_{2}(0.49-$ 4.47\%, 0.58), $\mathrm{Al}_{2} \mathrm{O}_{3}$ (3.77-15.24\%, 2.50), ${ }^{\mathrm{T}} \mathrm{Fe}_{2} \mathrm{O}_{3}$ (2.66-41.01\%, $5.42), \mathrm{MnO}(0.04-0.26 \%, 0.03), \mathrm{MgO}(0.46-2.19 \%, 0.42), \mathrm{CaO}$ (1.01-9.97\%, 1.92), $\mathrm{Na}_{2} \mathrm{O}(0.96-2.95 \%, 0.47), \mathrm{K}_{2} \mathrm{O}(1.24-3.98 \%$, $0.37), \mathrm{P}_{2} \mathrm{O}_{5}(0.05-0.23 \%, 0.03)$, As (4.6-16 ppm, 2.61), Cd (0.08$4.87 \mathrm{ppm}, 0.73), \mathrm{Cr}$ (12-86 ppm, 17.85), Cu (8-143 ppm, 23.03), $\mathrm{Pb}$ (19-98 ppm, 11.16), Ni (7-59 ppm, 10.38), V (23-145 ppm, 26.02), and $\mathrm{Zn}$ (20-120 ppm, 23.17). High SD values for ${ }^{\mathrm{T}} \mathrm{Fe}_{2} \mathrm{O}_{3}$, $\mathrm{Cr}, \mathrm{V}, \mathrm{Zn}, \mathrm{Ni}, \mathrm{Cu}$, and $\mathrm{Pb}$ are probably either due to different textural characteristics of sediments or the variable riverine influence in different transects sampled and/or influence of basaltic outcrops in some sampled locations (e.g., D03, D11, and D13 in Figure 2), as these three stations contain extremely high contents of these elements (Supplementary Table 1). Range and mean values obtained in this study are similar to the reported values of major and trace elements in surface sediments of the eastern part of the GOT (Dou et al., 2013) as well as in riverine sediments and soils in the Hainan Island (Zhao et al., 2015; Jiang et al., 2018).

\section{DISCUSSION}

\section{Major Element Geochemistry}

Sediments in coastal and offshore areas are mixtures of aluminosilicates and carbonate debris with minor content of organic matter. For the geochemical appraisal of sediments, previous studies have provided a variety of reference materials such as upper continental crust (UCC; Taylor and McLennan, 1985), upper crust of Yangtze Craton (UC-YC; Gao et al., 1998), average shale (AS; Turekian and Wedepohl, 1961), PostArchaean Australian shale (PAAS; Taylor and McLennan, 1985) and North American shale composite (NASC; Gromet et al., 1984). In this study, the chemical compositions of UC-YC and average shale along with UCC are used for the purpose of initial evaluation of geochemical characteristics of sediments. We choose the UC-YC because Hainan Island and South China share 
almost similar lithological characteristics, whereas average shale is compositionally compatible with the fine fraction $(<63 \mu \mathrm{m})$ of most estuarine and coastal sediments (Loring and Rantala, 1992).

Among four transects (A-D) investigated in this study, most major elements ( $\mathrm{Ti}, \mathrm{Mn}, \mathrm{Mg}, \mathrm{Na}$, and $\mathrm{P}$ ) spatially show more or less similar mean concentrations in both bulk $(<230 \mu \mathrm{m})$ and fine $(<63 \mu \mathrm{m})$ sediments (Figure 3). However, Al varied between $4.88 \pm 1.81$ and $7.29 \pm 0.35 \%$ in bulk sediments and from $4.11 \pm 2.38$ to $7.29 \pm 0.51 \%$ in fine sediments, with higher contents in the northern transects (A and B; Figure 3) and lower contents in the southern transect (D) (Figure 2). Likewise, Fe spatially varied from $3.06 \pm 0.63$ to $4.20 \pm 0.63 \%$ and $2.86 \pm 0.45$ to $15.55 \pm 11.86 \%$ in bulk and fine sediments, respectively, with the highest $\mathrm{Fe}$ is noted in transect D (Figure 3), especially at station D03, which is proximal to the confluence of Changhua River. $\mathrm{Ca}$ and $\mathrm{K}$ spatially vary slightly in both bulk and fine sediments (Figure 3).

Table 1 compares the mean contents of major elements of this study with data from the UCC (Taylor and McLennan, 1985), UC-YC (Gao et al., 1998) and average shale (Turekian and Wedepohl, 1961). Mean values of most elements, except Ti, $\mathrm{Fe}, \mathrm{Ca}$, and $\mathrm{Na}$, fluctuate around those values in average shale and UC-YC, suggesting that sediments were primarily derived from rocks in the hinterland that surrounds the Gulf. Ratios of elements in sediments divided by the same elements in the reference materials can illustrate the leach and enrichment status of major elements during weathering processes, as the ratio equal to 1 suggests no enrichment/depletion, $>1$ indicates enrichment and $<1$ indicates depletion (Liu et al., 2012). It is evident from Figure 4 that $\mathrm{Ti}, \mathrm{Fe}$, and $\mathrm{Na}$ show ratios $>1$, indicating their enrichment in sediments than the reference compositions due likely to the influence of ilmenite ( $\mathrm{Ti}$ and $\mathrm{Fe}$ ) and sea salt ( $\mathrm{Na}$, as sea salt is associated mostly with fine sediments).

Calvert et al. (1993) suggested that assessment of major elemental variation in terms of elemental normalization would

TABLE 1 | Summary statistics of major elements (\%) in surface sediments along the west coast of Hainan Island, the Gulf of Tonkin.

\begin{tabular}{|c|c|c|c|c|c|c|c|c|c|}
\hline & $\mathrm{Ti}$ & Al & $\mathrm{Fe}$ & Mn & $\mathrm{Ca}$ & $\mathrm{Mg}$ & $\mathrm{Na}$ & $\mathbf{K}$ & $\mathbf{P}$ \\
\hline \multicolumn{10}{|c|}{ Fine sediments $(<63 \mu \mathrm{m})$} \\
\hline Minimum & 0.33 & 1.99 & 2.08 & 0.03 & 0.91 & 0.41 & 0.33 & 1.03 & 0.04 \\
\hline Maximum & 2.68 & 8.07 & 28.68 & 0.20 & 5.70 & 1.32 & 2.19 & 2.47 & 0.10 \\
\hline Mean & 0.67 & 6.58 & 5.02 & 0.06 & 2.33 & 1.04 & 1.47 & 1.82 & 0.06 \\
\hline $\mathrm{SD}(N=25)$ & 0.47 & 1.35 & 5.27 & 0.03 & 1.22 & 0.22 & 0.33 & 0.24 & 0.01 \\
\hline \multicolumn{10}{|c|}{ Bulk sediments $(<230 \mu \mathrm{m})$} \\
\hline Minimum & 0.29 & 3.63 & 1.87 & 0.03 & 0.72 & 0.28 & 0.81 & 1.52 & 0.02 \\
\hline Maximum & 0.72 & 7.94 & 5.44 & 0.07 & 7.12 & 1.31 & 2.13 & 3.30 & 0.07 \\
\hline Mean & 0.52 & 6.56 & 3.77 & 0.06 & 2.30 & 1.03 & 1.47 & 1.93 & 0.05 \\
\hline $\mathrm{SD}(N=25)$ & 0.12 & 1.32 & 0.85 & 0.01 & 1.53 & 0.29 & 0.38 & 0.36 & 0.01 \\
\hline aUCC & 0.41 & 8.04 & 3.50 & 0.06 & 3.00 & 1.33 & 2.89 & 2.80 & 0.07 \\
\hline bUC-YC & 0.39 & 7.40 & 2.33 & 0.08 & 1.94 & 1.39 & 2.15 & 2.11 & 0.06 \\
\hline${ }^{\mathrm{c}}$ Average Shale & 0.46 & 8.80 & 4.72 & 0.09 & 1.60 & 1.50 & 0.59 & 2.66 & 0.07 \\
\hline
\end{tabular}

normally yield better understanding of elemental behaviors because such ratios can be interpreted in terms of the texture and mineralogy. The assumption of such normalization is that the reference element used such as $\mathrm{Al}$ or $\mathrm{Li}$ represents a certain mineral fraction of the sediments (Loring, 1991; Loring and Rantala, 1992). Since $\mathrm{Al}$ is a conservative indicator for the terrigenous source and its anthropogenic input is very limited (Nath et al., 1989; Loring and Rantala, 1992), here we prefer $\mathrm{Al}$ as a normalizer. Element/Al ratios of all major elements show more or less similar patterns of element/Al ratios in UC-YC and average shale (Table 2), suggesting that these sediments were largely sourced from erosion and/or chemical weathering of rocks from the surrounding landmasses (most likely Hainan Island and Leizhou Peninsula; Figure 2). $\mathrm{Ti}$ is a refractory element and is immobile in the marine environment and thus is considered to be detrital in origin (Bischoff et al., 1979). The mean Ti/Al ratios of bulk (0.08) and fine $(0.14)$ sediments are greater than the $\mathrm{Ti} / \mathrm{Al}$ ratio in $\mathrm{UC}-\mathrm{YC}$ (0.05) and average shale (0.05), while the Al-normalized Fe (0.58 and 1.20), Mn (0.009 and 0.013), Mg (0.16 and 0.16), K (0.31 and 0.29$)$, and $P(0.008$ and 0.010$)$ are more or less similar to these ratios both in UC-YC and average shale (Table 2). The linear regression between $\mathrm{Al}$ and major elements such as $\mathrm{Mg}$ $(r=0.81)$ and $\mathrm{Na}(r=0.69)$ indicate that these elements were probably derived from terrigenous source (Table 3$)$. The strong positive correlation of $\mathrm{Ti}$ with $\mathrm{Fe}(r=0.96)$, Mn $(r=0.93)$, and $\mathrm{P}(r=0.71)$ suggests either the presence of ilmenite mineral in sediments or early diagenesis and associated Fe-Mn oxyhydroxides precipitation in the surface sediments and/or combination of both (Chen and Selvaraj, 2008).

Smaller cations such as $\mathrm{Ca}, \mathrm{Na}$, and $\mathrm{Sr}$ are selectively leached during weathering processes (Figure 4), while larger cations remain fixed in the weathered detritus (Nesbitt and Markovics, 1980; Fedo et al., 1996). The changes in composition of siliciclastic sediments can help to investigate the probable source rocks where from sediments were derived. Quantitative determination of weathering conditions of sediments can thus be made by the calculation of chemical index of alteration (CIA; Nesbitt and Young, 1982) and chemical index of weathering (CIW; Harnois, 1988) according to the following formulas:

$$
\begin{gathered}
C I A=\left[\frac{\mathrm{Al}_{2} \mathrm{O}_{3}}{\mathrm{Al}_{2} \mathrm{O}_{3}+\mathrm{CaO}^{*}+\mathrm{Na}_{2} \mathrm{O}+\mathrm{K}_{2} \mathrm{O}}\right] \times 100 \\
C I W=\left[\frac{\mathrm{Al}_{2} \mathrm{O}_{3}}{\mathrm{Al}_{2} \mathrm{O}_{3}+\mathrm{CaO}^{*}+\mathrm{Na}_{2} \mathrm{O}}\right] \times 100
\end{gathered}
$$

In these equations, all contents of major oxides are in molar proportions and $\mathrm{CaO}^{*}$ refers to $\mathrm{CaO}$ associated with the silicate fraction of the sample. By calculating the loss of mobile elements $(\mathrm{Ca}, \mathrm{Na}$, and $\mathrm{K}$ ) against immobile $\mathrm{Al}$, these weathering indexes can reflect the conditions of chemical weathering of source rocks. CIA values between 45 and 55 refer to absence of weathering, and CIA lower than 60 means low weathering, between 60 and 80 stand for moderate chemical weathering, and CIA values $>80$ indicate intense weathering of source rocks (Nesbitt and Young, 1982; Selvaraj and Chen, 2006; Liu et al., 2012). In the present study, mean CIA values of fine and bulk sediments are 

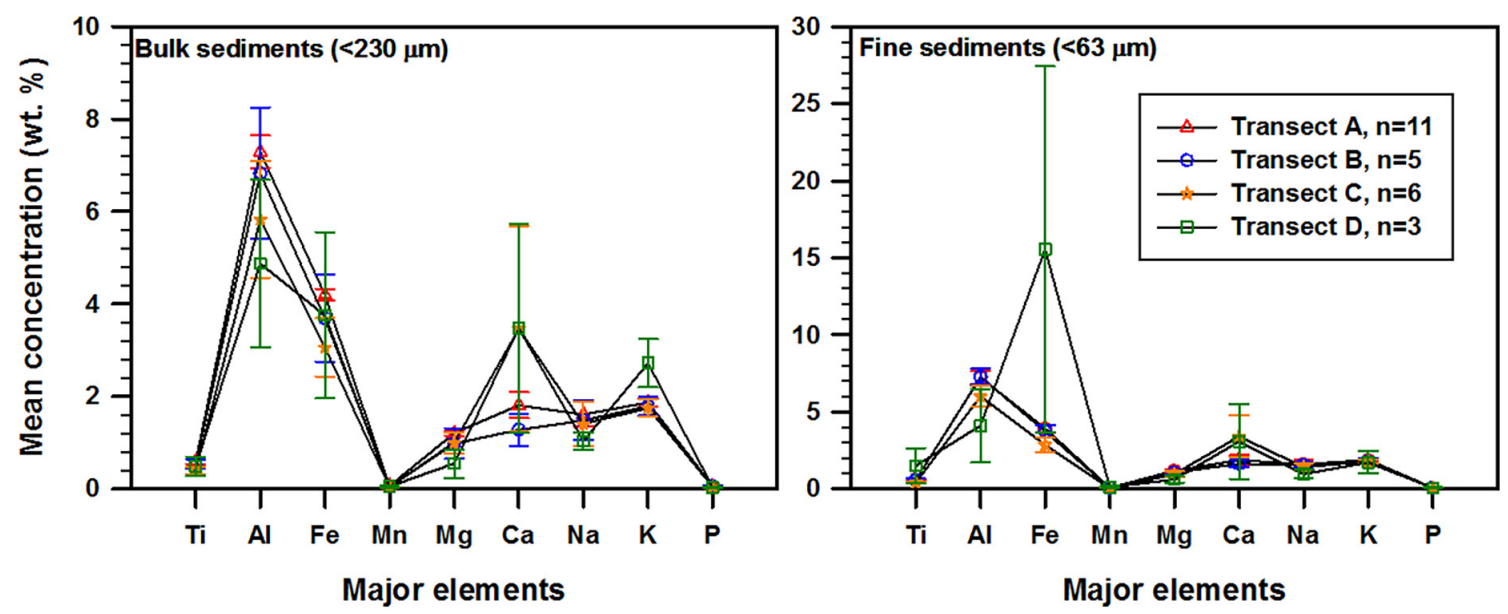

FIGURE 3 | Transect-wise (A-D) mean ( \pm SD) concentrations of major elements in bulk ( $<230 \mu \mathrm{m})$ and fine $(<63 \mu \mathrm{m})$ sediments investigated from off northwest Hainan Island, the Gulf of Tonkin, showing the spatial variability. Note the odd trend of samples from transect $D$ due to the riverine influence with heavy mineral dominance.

TABLE 2 | Summary statistics of major element/Al ratios in surface sediments along the west coast of Hainan Island, the Gulf of Tonkin, and their weathering indexes (CIA and CIW) compared with reference compositions.

\begin{tabular}{|c|c|c|c|c|c|c|c|c|c|c|}
\hline & \multicolumn{8}{|c|}{ Element/Al ratio } & \multicolumn{2}{|c|}{ Weathering indexes } \\
\hline & Ti/Al & $\mathrm{Fe} / \mathrm{Al}$ & $\mathrm{Mn} / \mathrm{Al}$ & $\mathrm{Ca} / \mathrm{Al}$ & $\mathrm{Mg} / \mathrm{Al}$ & $\mathrm{Na} / \mathrm{Al}$ & K/Al & P/Al & ${ }^{\mathrm{d}} \mathrm{CIA}$ & ${ }^{e} \mathrm{CIW}$ \\
\hline \multicolumn{11}{|c|}{ Fine sediments $(<63 \mu \mathrm{m})$} \\
\hline Minimum & 0.05 & 0.41 & 0.006 & 0.14 & 0.11 & 0.14 & 0.20 & 0.006 & 68 & 78 \\
\hline Maximum & 1.34 & 14.38 & 0.100 & 1.56 & 0.21 & 0.36 & 0.51 & 0.050 & 75 & 97 \\
\hline Mean & 0.14 & 1.20 & 0.013 & 0.42 & 0.16 & 0.23 & 0.29 & 0.010 & 72 & 81 \\
\hline $\mathrm{SD}(N=25)$ & 0.26 & 2.81 & 0.019 & 0.36 & 0.02 & 0.05 & 0.07 & 0.009 & 1 & 3 \\
\hline \multicolumn{11}{|c|}{ Bulk sediments (<230 $\mu \mathrm{m})$} \\
\hline Minimum & 0.06 & 0.16 & 0.005 & 0.16 & 0.07 & 0.17 & 0.23 & 0.005 & 56 & 67 \\
\hline Maximum & 0.20 & 1.09 & 0.015 & 1.67 & 0.24 & 0.30 & 0.82 & 0.010 & 74 & 81 \\
\hline Mean & 0.08 & 0.58 & 0.009 & 0.40 & 0.16 & 0.022 & 0.31 & 0.008 & 71 & 79 \\
\hline $\mathrm{SD}(N=25)$ & 0.03 & 0.12 & 0.002 & 0.38 & 0.03 & 0.03 & 0.13 & 0.001 & 4 & 3 \\
\hline aUCC & 0.04 & 0.44 & 0.007 & 0.38 & 0.16 & 0.36 & 0.35 & 0.008 & 46 & 52 \\
\hline${ }^{b} \cup C-Y C$ & 0.05 & 0.50 & 0.010 & 0.26 & 0.19 & 0.29 & 0.29 & 0.018 & 56 & 59 \\
\hline${ }^{\mathrm{c}}$ Average Shale & 0.05 & 0.54 & 0.010 & 0.18 & 0.17 & 0.07 & 0.30 & 0.008 & 65 & 76 \\
\hline
\end{tabular}

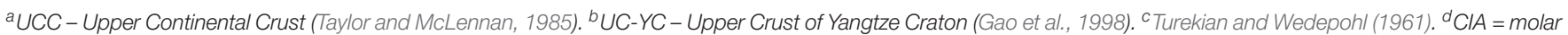
$\left[\mathrm{Al}_{2} \mathrm{O}_{3} /\left(\mathrm{Al}_{2} \mathrm{O}_{3}+\mathrm{CaO}^{*}+\mathrm{Na}_{2} \mathrm{O}+\mathrm{K}_{2} \mathrm{O}\right)\right] \times 100$ (Nesbitt and Young, 1982). ${ }^{e} \mathrm{ClW}=$ molar $\left[\mathrm{Al}_{2} \mathrm{O} 3 /\left(\mathrm{Al}_{2} \mathrm{O}_{3}+\mathrm{CaO} *+\mathrm{Na}_{2} \mathrm{O}\right)\right] \times 100(\mathrm{Harnois}, 1988)$.

72 and 71 (Table 2), respectively, indicating moderate chemical weathering of source rocks. Consistent to this interpretation, the mean CIW values of fine and bulk sediments are 81 and 79 (Table 2), respectively. The CIA and CIW values together reveal that the sediments of present study might be dominantly derived from felsic source rocks (e.g., granite, granodiorite) that have undergone moderate chemical weathering (Table 2).

In order to get information about weathering trends, the molar proportions of major oxides of samples are plotted in $\mathrm{A}-\mathrm{CN}-\mathrm{K}\left(\mathrm{Al}_{2} \mathrm{O}_{3}-\left(\mathrm{CaO}^{*}+\mathrm{Na}_{2} \mathrm{O}\right)-\mathrm{K}_{2} \mathrm{O}\right)$ and A-CNK-FM $\left(\mathrm{Al}_{2} \mathrm{O}_{3}-\left(\mathrm{CaO}^{*}+\mathrm{Na}_{2} \mathrm{O}+\mathrm{K}_{2} \mathrm{O}\right)-\mathrm{FeO}^{\mathrm{T}}+\mathrm{MgO}\right)$ ternary diagrams (Figure 5), along with reference compositions, including river particulates and different kinds of basalts. All samples of present study fall midway between the $\mathrm{Al}_{2} \mathrm{O}_{3}$ apex and feldspar join, in particular between illite and smectite compositions of $\sim 70-80$ CIA values. This indicates that the sediments of Gulf of Tonkin have undergone moderate weathering process during when $\mathrm{Al}_{2} \mathrm{O}_{3}$ content enriched, while $\mathrm{CaO}, \mathrm{Na}_{2} \mathrm{O}$, and $\mathrm{K}_{2} \mathrm{O}$ depleted variably. Distributions of some fine and bulk sediments in Figure 5 are not parallel to the $\mathrm{Al}_{2} \mathrm{O}_{3}-\mathrm{CaO}+\mathrm{Na}_{2} \mathrm{O}$ join, implying that the sediments were not only derived from felsic (granite) sources (Fedo et al., 1996), but may also be derived from basalts. Consistent to this inference, in a mafic diagram of A-CNKFM, almost all samples plot between feldspar and smectite compositions with a few samples plot toward $\mathrm{FeO}^{\mathrm{T}}+\mathrm{MgO}$ apex, suggesting the preferential enrichment of $\mathrm{Fe}$ and $\mathrm{Mg}$ oxides in these samples due likely to basaltic source rocks, although most samples were derived from granitic-charnockite sources. 
TABLE 3 | Correlation coefficients ( $r$ ) between different pairs of sedimentological and geochemical variables $(N=50)$.

\begin{tabular}{|c|c|c|c|c|c|c|c|c|c|c|c|c|c|c|c|c|c|c|c|c|c|}
\hline & $\mathrm{Ti}$ & Al & $\mathrm{Fe}$ & $\mathrm{Ca}$ & Mg & $\mathrm{Na}$ & K & $\mathbf{P}$ & Mn & As & Cd & $\mathrm{Cr}$ & $\mathrm{Cu}$ & $\mathrm{Pb}$ & $\mathrm{Ni}$ & $\mathbf{v}$ & $\mathrm{Zn}$ & Sand & Clay & TOC & $\mathrm{CaCO}_{3}$ \\
\hline $\mathrm{Al}$ & & 1.00 & -0.45 & -0.54 & 0.81 & 0.69 & 0.13 & 0.26 & -0.20 & 0.44 & -0.56 & 0.63 & 0.15 & 0.37 & 0.82 & 0.55 & 0.78 & -0.10 & 0.07 & 0.70 & -0.18 \\
\hline $\mathrm{Ca}$ & & & & 1.00 & -0.22 & -0.30 & -0.14 & -0.15 & 0.03 & -0.26 & 0.16 & -0.38 & -0.22 & -0.29 & -0.43 & -0.42 & -0.50 & 0.06 & -0.09 & -0.48 & 0.63 \\
\hline $\mathrm{Mg}$ & & & & & 1.00 & 0.74 & -0.09 & 0.35 & 0.01 & 0.48 & -0.40 & 0.73 & -0.02 & 0.42 & 0.81 & 0.61 & 0.78 & -0.10 & 0.08 & 0.44 & -0.15 \\
\hline $\mathrm{P}$ & & & & & & & & 1.00 & 0.77 & 0.38 & 0.47 & 0.78 & -0.02 & 0.45 & 0.42 & 0.88 & 0.69 & -0.33 & 0.21 & 0.07 & 0.00 \\
\hline $\mathrm{Mn}$ & & & & & & & & & 1.00 & 0.42 & 0.80 & 0.43 & 0.17 & 0.35 & -0.02 & 0.62 & 0.38 & -0.18 & 0.11 & -0.27 & -0.11 \\
\hline As & & & & & & & & & & 1.00 & 0.06 & 0.41 & 0.49 & 0.36 & 0.33 & 0.53 & 0.60 & -0.06 & 0.09 & 0.32 & -0.19 \\
\hline $\mathrm{Cd}$ & & & & & & & & & & & 1.00 & 0.05 & 0.13 & 0.35 & -0.29 & 0.23 & -0.04 & -0.10 & 0.06 & -0.42 & -0.10 \\
\hline $\mathrm{Cr}$ & & & & & & & & & & & & 1.00 & -0.19 & 0.50 & 0.77 & 0.93 & 0.90 & -0.23 & 0.17 & 0.24 & -0.24 \\
\hline $\mathrm{Zn}$ & & & & & & & & & & & & & & & & & 1.00 & -0.04 & -0.02 & 0.45 & -0.28 \\
\hline Sand & & & & & & & & & & & & & & & & & & 1.00 & -0.89 & -0.03 & -0.05 \\
\hline Clay & & & & & & & & & & & & & & & & & & & 1.00 & 0.06 & -0.10 \\
\hline TOC & & & & & & & & & & & & & & & & & & & & 1.00 & -0.14 \\
\hline $\mathrm{CaCO}_{3}$ & & & & & & & & & & & & & & & & & & & & & 1.00 \\
\hline
\end{tabular}

Bold indicates correlation significant at the 0.01 leve l; Italics indicates correlation significant at the 0.05 leve I.

\section{Trace Element Geochemistry}

Spatially, $\mathrm{Cr}$ and Ni varied from $24 \pm 11$ to $78 \pm 5 \mathrm{ppm}$ and $12 \pm 5$ to $37 \pm 3 \mathrm{ppm}$ in bulk sediments with higher and lower concentrations are evident, consistent to the Al behavior, in transects A and D, respectively (Figure 6). Compared to these two trace elements, $\mathrm{V}$ and $\mathrm{Zn}$ showed large variations (V: $45 \pm 22-$ $110 \pm 7$ ppm; Zn: $49 \pm 30-107 \pm 7$ ppm) in bulk sediments. The former two trace elements spatially varied more narrowly among transects with high concentrations (Cr: $53 \pm 28-77 \pm 4 \mathrm{ppm}$ and Ni: 28 $\pm 3-38 \pm 4 \mathrm{ppm}$ ) in fine sediments, whereas the latter two trace elements varied widely (V: $69 \pm 11-106 \pm 9 \mathrm{ppm}$ and $\mathrm{Zn}$ : $68 \pm 12-98 \pm 10 \mathrm{ppm})$. Similar variability of these elements is also evident in fine sediments, but with less magnitude (Figure 6). Among four transects investigated, bulk and fine sediments from three northern transects $(\mathrm{A}, \mathrm{B}$, and $\mathrm{C})$ behave spatially almost similar, but the sediments from the fourth southernmost transect (D; Figure 2) are characteristically different with high contents of trace elements because of direct riverine influence with heavy mineral dominance. Spatial variability of trace elements, in particular $\mathrm{Cr}, \mathrm{Ni}, \mathrm{V}$, and $\mathrm{Zn}$, is larger in bulk than fine sediments, suggesting that dilution by coarse fraction likely plays a critical role in controlling most trace elements variability in sediments, off northwest coast of Hainan Island, the Gulf of Tonkin (Figure 6).

Table 4 compares the mean concentrations of six selected trace metals in fine and bulk sediments with concentrations of those metals obtained from other coastal regions of East China as well as reference compositions such as UCC, UC-YC and average shale. Mean As content in fine and bulk sediments
(11 ppm) is similar to its level in average shale, but lower than the As content in sediments of Xiamen Bay and northern South China Sea (Table 4). Cadmium contents in fine $(0.37 \mathrm{ppm})$ and bulk $(0.22 \mathrm{ppm})$ sediments fall within the range published in previous studies, but higher than the Cd content in UCC $(0.1 \mathrm{ppm})$ and UC-YC $(0.08 \mathrm{ppm})$ and roughly similar to $\mathrm{Cd}$ in average shale $(0.3 \mathrm{ppm})$, but lower than found in Shenzhen and Quanzhou Bays sediments (Yu et al., 2008; Zuo et al., 2009). Concentrations of $\mathrm{Cd}$ in fine sediments are relatively higher than those in bulk sediments due likely to the different adsorption capability of mud and sand. The mean $\mathrm{Cr}$ values in fine $(69 \mathrm{ppm})$ and bulk (64 ppm) sediments are lower than that in average shale $(90 \mathrm{ppm})$ but similar to the reported $\mathrm{Cr}$ in UCYC (66 ppm) and also fall within the range reported for most coastal regions in East China (Table 4). Moreover, $\mathrm{Cu}$ values of fine and bulk sediments are apparently lower than $\mathrm{Cu}$ in average shale and UC-YC. $\mathrm{Pb}$ in fine ( $35 \mathrm{ppm})$ and bulk (36 ppm) sediments are higher than those in average shale $(20 \mathrm{ppm})$ and UC-YC (17 ppm), indicating that surface sediments of Gulf of Tonkin are likely contaminated by $\mathrm{Pb}$ from anthropogenic sources. Zinc concentrations in fine and bulk sediments (87 and $90 \mathrm{ppm})$ lie between its concentration in UC-YC (70 ppm) and average shale $(95 \mathrm{ppm})$.

Sediments are considered as an ideal sink for many trace metals, which could switch from sediments to the overlying water column due to changes in $\mathrm{pH}$ and Eh of depositional environments (Sundelin and Eriksson, 2001). Urbanization and industrialization have caused an increasing metal pollution in the coastal and estuarine regions of China for the past around 2-3 
TABLE 4 | Mean concentrations (ppm) of total trace metals in coastal surface sediments in the Gulf of Tonkin compared with the reported values of trace metals from other areas of the Gulf and China. Also shown are the values of trace metals from some reference materials.

\begin{tabular}{|c|c|c|c|c|c|c|c|}
\hline & As & Cd & $\mathrm{Cr}$ & $\mathrm{Cu}$ & $\mathrm{Pb}$ & $\mathrm{Zn}$ & References \\
\hline $\begin{array}{l}\text { Fine sediments } \\
(N=25)\end{array}$ & 11 & 0.37 & 69 & 26 & 35 & 87 & This study \\
\hline $\begin{array}{l}\text { Bulk sediments } \\
(N=25)\end{array}$ & 11 & 0.22 & 64 & 28 & 36 & 90 & This study \\
\hline $\begin{array}{l}\text { Beibu Bay (Nanliu } \\
\text { River estuary) }\end{array}$ & 18 & 0.08 & 45 & 68 & 34 & 57 & Xia et al., 2011 \\
\hline $\begin{array}{l}\text { Beibu } \\
\text { Gulf-sediment core }\end{array}$ & 3 & NR & 46 & 16 & 1.5 & 48 & Xia et al., 2013 \\
\hline Beibu Bay (Eastern) & 10 & 0.16 & 54 & 58 & 28 & 67 & Dou et al., 2013 \\
\hline Guangxi Inshore & 14 & $N R$ & 40 & 10 & 21 & $N R$ & Lian, 2002 \\
\hline $\begin{array}{l}\text { Northern South } \\
\text { China Sea }\end{array}$ & 20 & $N R$ & 80 & 35 & 60 & 150 & $\begin{array}{l}\text { Gan et al., 2003; } \\
\text { Zhang and Du, } \\
2005\end{array}$ \\
\hline Liaodong Bay & $N R$ & 1.16 & NR & 18 & 24 & 105 & Zhou et al., 2004 \\
\hline $\begin{array}{l}\text { Xiamen Western } \\
\text { Harbor }\end{array}$ & $N R$ & 0.14 & 81 & 37 & 47 & 157 & Yang et al., 2007 \\
\hline Beihai Coast & 9 & 0.22 & NR & 13 & 17 & $N R$ & Xia et al., 2008 \\
\hline Shenzhen Bay & $N R$ & 4.61 & 115 & 69 & 38 & 489 & Zuo et al., 2009 \\
\hline $\begin{array}{l}\text { Xiamen Bay } \\
\text { (Yundong Lagoon) }\end{array}$ & 34 & NR & 72 & 57 & 88 & 179 & Chen et al., 2010 \\
\hline Yueqing Bay & 18 & 0.21 & 51 & 46 & 30 & 128 & Wang et al., 2015 \\
\hline $\begin{array}{l}\text { Upper Continental } \\
\text { Crust (UCC) }\end{array}$ & 1.5 & 0.10 & 83 & 25 & 17 & 71 & $\begin{array}{l}\text { Taylor and } \\
\text { McLennan, } 1985\end{array}$ \\
\hline $\begin{array}{l}\text { Upper Crust of } \\
\text { Yangtze Craton } \\
\text { (UC-YC) }\end{array}$ & 3.6 & 0.08 & 66 & 25 & 17 & 70 & Gao et al., 1998 \\
\hline Average Shale & 13.0 & 0.30 & 90 & 45 & 20 & 95 & $\begin{array}{l}\text { Turekian and } \\
\text { Wedepohl, } 1961\end{array}$ \\
\hline
\end{tabular}

NR - Not reported.

decades. Statistical data from the Chinese government indicated that nearly $30,000 \mathrm{~km}^{2}$ of coastal areas of China have already been contaminated/polluted by trace metals (NBO, 2009). These data further revealed that anthropogenic inputs through industrial and sewage discharges as well as mining and smelting operations are important sources of metal contamination in Chinese coastal areas. Comparison of trace elemental concentrations of sediments in the Gulf of Tonkin with other coastal regions of East China reveals that concentrations of trace metals in the study area are lower than average values reported for other coastal regions (Table 4), suggesting the unpolluted nature of the coastal sites of the Gulf. This comparison further reveals that the pollution state of our study area is not as serious as other coastal regions in mainland China. The highly developed areas, such as Yangtze River delta, the Pearl River delta, and the Beijing-Tianjin-Tangshan industrial area, contain more serious problems of trace metal pollution than other relatively less developed areas (Pan and Wang, 2012). Our literature survey of papers published from estuarine and coastal regions in China revealed that metals such as $\mathrm{As}, \mathrm{Cd}, \mathrm{Cr}, \mathrm{Cu}, \mathrm{Hg}, \mathrm{Ni}$, $\mathrm{Pb}$, and $\mathrm{Zn}$ are main pollutants and their concentrations are in general higher in northern coastal regions of East China. Likewise, the Pearl River delta, one of the most industrialized and urbanized regions in South China, seems to contribute the majority of metal pollutants to southeast coastal area of China. Meng et al. (2013) used integrated biomarker response to assess the environmental quality of ecosystem along the GOT. They also investigated metal and PCBs contents in surface sediments collected along the coast of GOT, northern South China Sea, and suggested that the contamination degree in whole area of the Gulf was moderate. As there were no significant correlations between biomarkers and pollutants, Meng et al. (2013) attributed this condition to low amount of contaminants, which were not enough to promote significant biomarker responses.

Table 3 shows correlation coefficients ( $r$ ) between different pairs of variables. The positive correlation of $\mathrm{Al}$ with $\mathrm{Mg}$ (0.81), $\mathrm{Na}$ (0.69), $\mathrm{Cr}$ (0.63), $\mathrm{Ni}(0.82), \mathrm{V}$ (0.55), and $\mathrm{Zn}$ (0.78) reveals the association of these elements in lattices of aluminosilicates derived from continental origin as well as their natural variability in sediments (Chen and Selvaraj, 2008). Titanium, another detrital indicator similar to $\mathrm{Al}$, is positively correlated with $\mathrm{Fe}$ (0.96), P (0.71), and Mn (0.93), confirming the presence of ferromagnesian minerals and ilmenite $\left(\mathrm{FeTiO}_{3}\right)$, given that titanium is known to be easily associated with Fe-oxide phases (Koschinsky et al., 1997; Jiang et al., 2018). Such interpretation is consistent with behaviors of $\mathrm{Cr}, \mathrm{Ni}, \mathrm{V}$ and $\mathrm{Zn}$, all showing linear relationships with $\mathrm{Al}, \mathrm{Fe}$, and $\mathrm{Ti}$ (Figure 7). As Hainan Island is rich in ilmenite, the above association of $\mathrm{Fe}, \mathrm{Ti}$, and $\mathrm{Mn}$ is likely influenced by heavy minerals, such as ilmenite, although we never undertake any mineralogical investigation in the present study to prove the presence of ilmenite phase in sediments. Sediment collected from the D03 site close to the confluence of Changhua River has a special characteristic as it has connected to the ocean

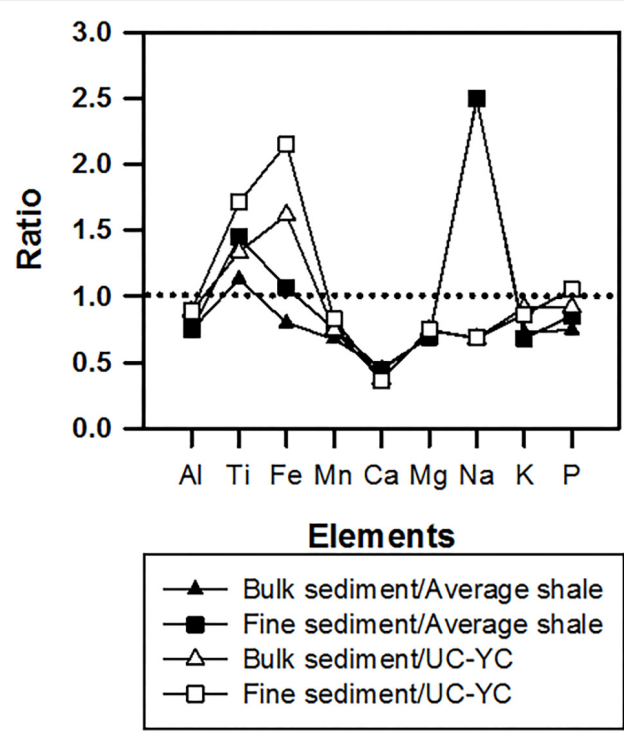

FIGURE 4 | Ratios of concentrations of major elements in surface sediments of the Gulf of Tonkin to those values in upper crust of Yangtze Craton (UC-YC) and average shale. 


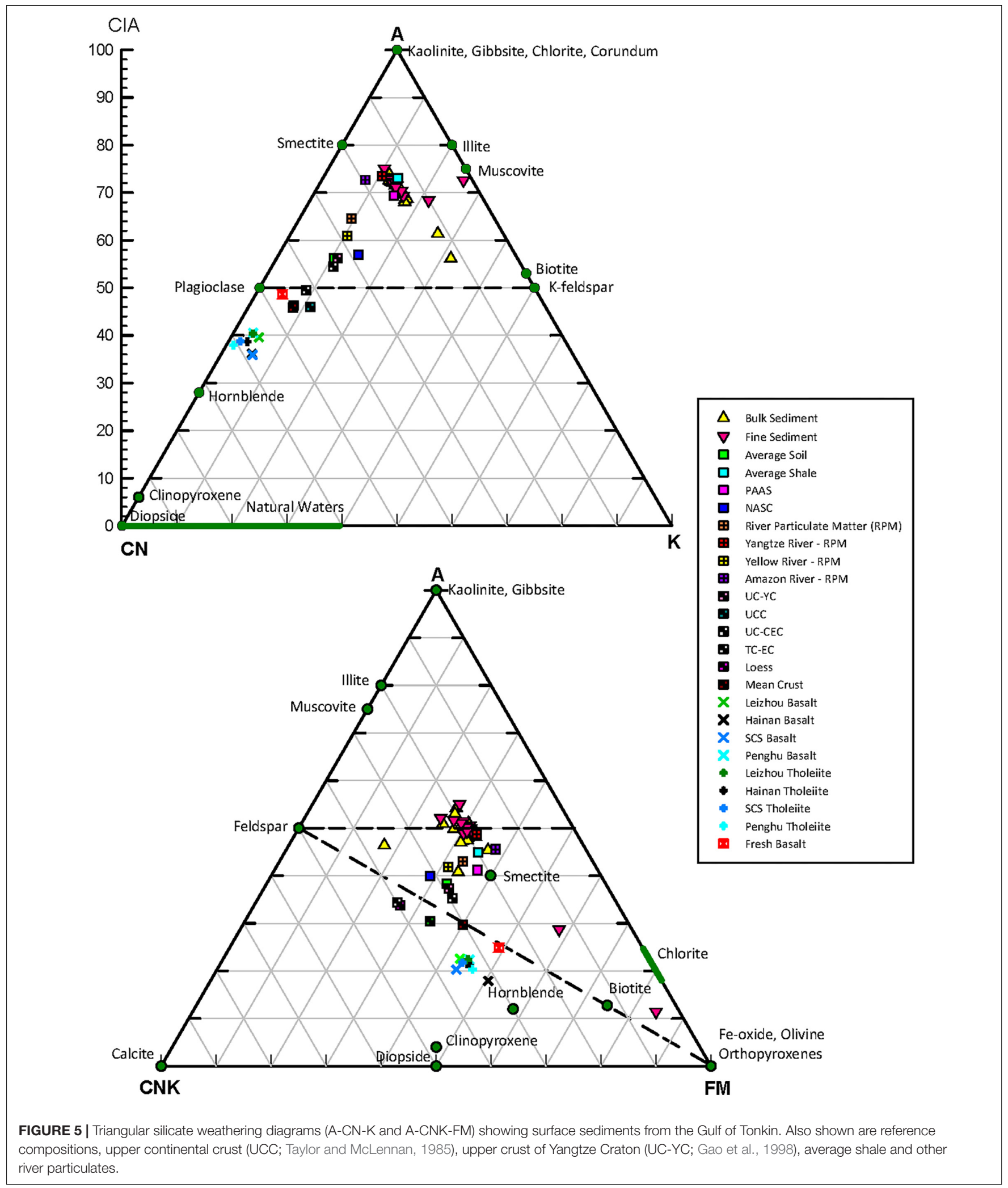

during flood tide and isolated during ebb tide. Thus surface sediment at this site may undergo early diagenetic enhancement of $\mathrm{Fe}-\mathrm{Mn}$ oxyhydroxides and also contains the highest $\mathrm{Fe}$ and Ti concentrations due to ilmenite. This interpretation is further supported by very high concentrations of $\mathrm{Mn}$ and other elements [P - 2300 ppm, Ti - 44723 ppm, Cr - 83 ppm, and 


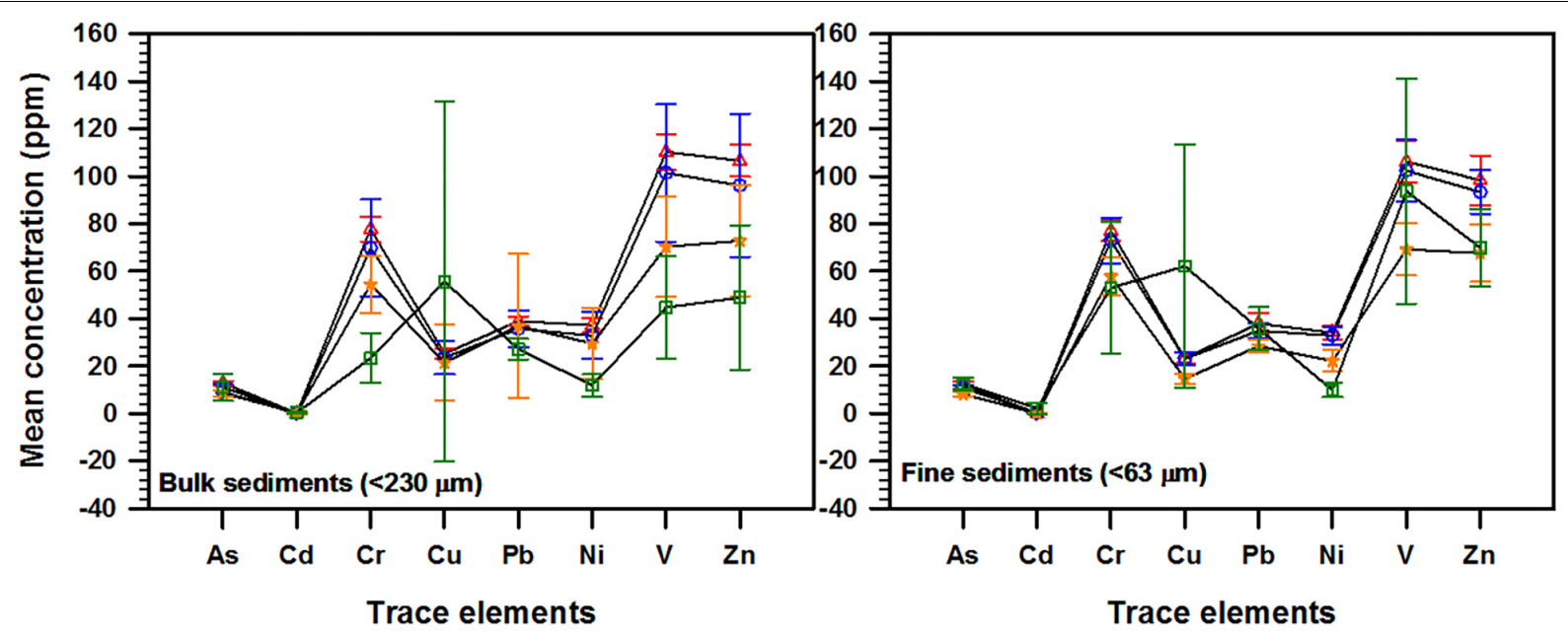

FIGURE 6 | Transect-wise (A-D) mean ( \pm SD) concentrations trace elements in bulk $(<230 \mu \mathrm{m})$ and fine $(<63 \mu \mathrm{m})$ sediments investigated from off northwest Hainan Island, the Gulf of Tonkin, illustrating spatial variabilities. Note the odd trend of samples from transect $\mathrm{D}$ due to the riverine influence with heavy mineral dominance.

V - $145 \mathrm{ppm}$ ] at D03 sampling site (Supplementary Table 1 and Figures 2, 3, 6).

\section{Normalization and Enrichment Factors}

Normalization is widely used as an appropriate approach to separate trace metals of natural sources from anthropogenic inputs with sediments. Previous studies have suggested that the normalization is a good way to distinguish these two sources in sediments. Common normalizers, including $\mathrm{Al}$ (Windom et al., 1989), Li (Loring, 1991), and Yb (Szefer et al., 1999). In this study, both $\mathrm{Al}$ and $\mathrm{Ti}$ were tried but finally $\mathrm{Al}$ was chosen for the purpose of normalization because $\mathrm{Al}$ has better correlation coefficients with other trace metals than Ti does (Figure 7 and Table 3). Anthropogenic emission of $\mathrm{Al}$ is very limited, implying that $\mathrm{Al}$ in surface sediments is almost from natural sources.

Normalization is also useful to calculate enrichment factor (EF) of trace metals. By calculating EF of trace metals, we can approximately distinguish anthropogenic contribution from natural sources. In this study, as sediments were mostly derived from physical erosion and/or chemical weathering of rocks from the surrounding landmasses (Figure 4), average shale and UC$\mathrm{YC}$ were chosen to be two reference materials for the calculation of EF by using the equation:

$$
E F=\frac{\left(\frac{M e}{A l}\right)_{\text {sample }}}{\left(\frac{M e}{A l}\right)_{\mathrm{UC}-\mathrm{YC} \text { or average shale }}}
$$

where $(\mathrm{Me} / \mathrm{Al})_{\text {sample }}$ and $(\mathrm{Me} / \mathrm{Al})_{\mathrm{UC}-\mathrm{YC} \text { or average shale }}$ are the concentrations of metal to $\mathrm{Al}$ ratio in the studied samples and in reference compositions such as UC-YC or average shale. Table 5 presents the calculated EF for eight trace elements (As, Cd, Cr, $\mathrm{Cu}, \mathrm{Ni}, \mathrm{Pb}, \mathrm{V}$, and $\mathrm{Zn}$ ) with respect to average shale and $\mathrm{UC}$ YC. Arsenic shows high mean EF values for both fine (3.72) and bulk (3.47) sediments with respect to UC-YC, whereas it exhibits relatively low mean EF values (1.22 and 1.14) compared to average shale. The high EF for $\mathrm{Cd}$ in fine sediments against average shale and UC-YC are obviously higher than EF of Cd in bulk sediments because of abnormal values that associated with sample D03 (23.3; Table 5), much greater than EF reported for other coastal regions. After excluding this site from the calculation, the mean EF for $\mathrm{Cd}$ in fine sediments is 1.04 against average shale and 3.38 against UC-YC. EF for $\mathrm{Pb}$ with respect to average shale (2.58 for fine and 2.44 for bulk sediments) and UCYC (2.55 for fine and 2.42 for bulk sediments) are higher than 2 , implying that some amount of $\mathrm{Pb}$ was from anthropogenic sources. In general, $\mathrm{EF}$ for $\mathrm{Cr}, \mathrm{Cu}, \mathrm{Ni}, \mathrm{V}$, and $\mathrm{Zn}$ both in fine and bulk sediments with respect to average shale and UC-YC are $<2$ (Table 5), indicating that these metals are mainly associated with aluminosilicates of terrigenous sources and anthropogenic input of these metals in the study area is less likely.

In this study, EF values vary significantly based on the usage of different reference materials. For instance, EFs with respect to UCC show extremely abnormal values for As in fine (range: 8.3930.77; mean 17.54) and bulk sediments (range: 7.58-36.68; mean 17.10), which are obviously higher than EFs of As with respect to average shale and UC-YC. Chen and Selvaraj (2008) pointed out that the UCC composition cannot be used as a reference material to investigate the anthropogenic impact on sediments derived from small oceanic island. In general, the calculation of EF of eight trace elements suggests that the investigated region is slightly contaminated only by $\mathrm{Pb}(\mathrm{EF}>2)$. EFs for fine sediments are slightly higher than that of bulk sediments for most investigated trace metals (Table 5), revealing the preferential association of trace elements with finer rather than coarser/bulk sediments, given that the former holds more surface area than the latter for adsorption of dissolved metals from the water column (Krumgalz et al., 1992).

\section{Elemental Provenance}

In order to determine the factors controlling major and trace elemental distribution in surface sediments, sedimentological and geochemical data were subjected to statistical analysis. 

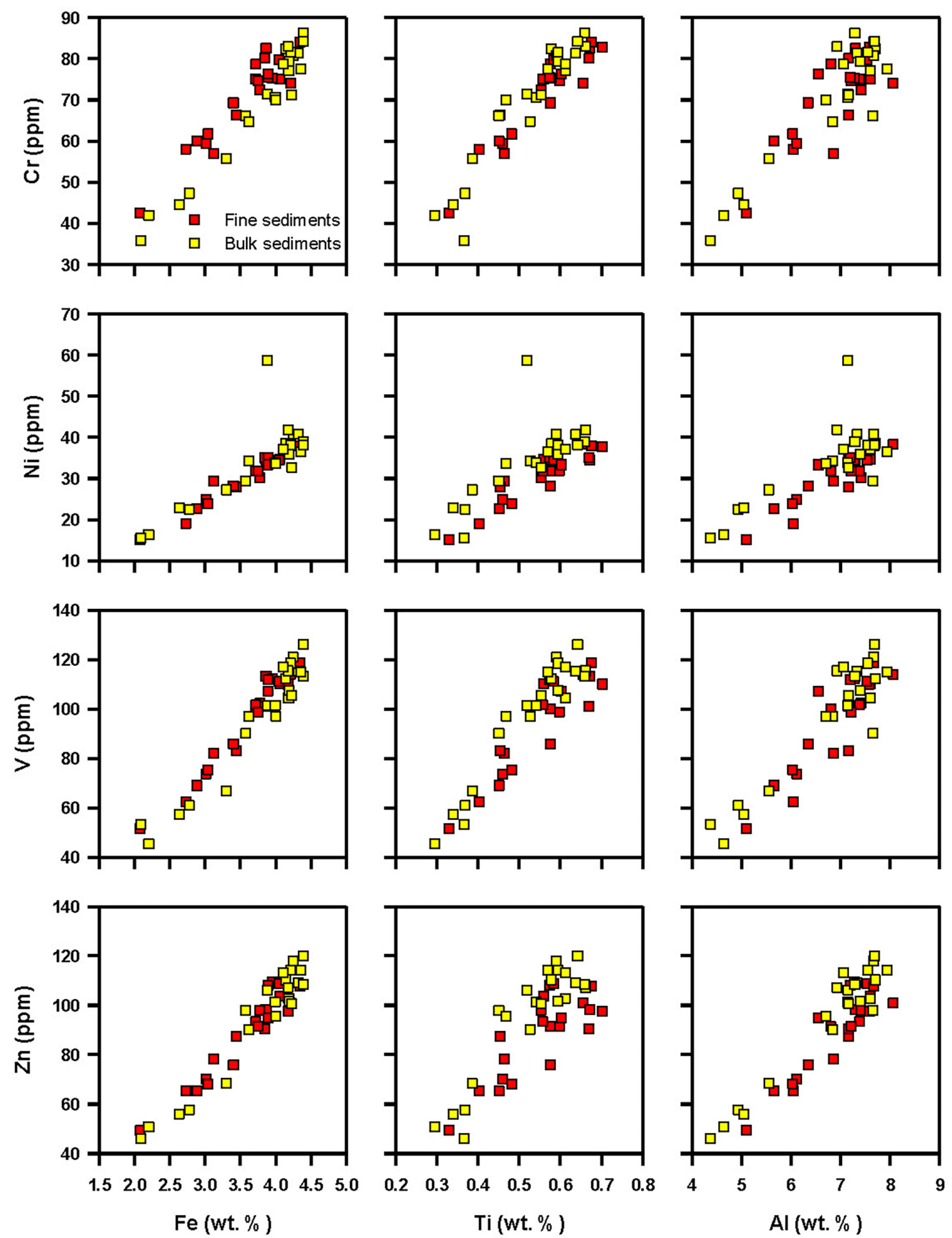

FIGURE 7 | Bi-plots showing linear relationships between major elements (Fe, Ti, and $\mathrm{Al}$ ) and trace elements (Cr, Ni, V, and $\mathrm{Zn}$ ) both in fine and bulk factions of surface sediments.

Geochemical factor analysis is a proper way to do this because it provides information about the association of metalinorganic and metal-organic phases (Winters and Buckley, 1992).
Therefore, the entire geochemical data set of bulk and fine sediments, including sand, silt and clay as well as TOC and $\mathrm{CaCO}_{3}$ contents, was run with the SPSS (version 17.0) software 
TABLE 5 | Summary statistics of enrichment factor (EF) calculated with respect to average shale (Turekian and Wedepohl, 1961) and the upper crust of Yangtze Craton (UC-YC; Gao et al., 1998) for coastal surface sediments from the northwest coast of Hainan Island. See section Normalization and Enrichment Factors for the calculation of EF.

\begin{tabular}{|c|c|c|c|c|c|c|c|c|}
\hline & As & Cd & $\mathrm{Cr}$ & $\mathrm{Cu}$ & $\mathrm{Ni}$ & $\mathrm{Pb}$ & $\mathbf{V}$ & $\mathrm{Zn}$ \\
\hline \multicolumn{9}{|c|}{ Fine sediments (EF with respect to average shale) } \\
\hline Minimum & 0.84 & 0.36 & 0.43 & 0.45 & 0.33 & 1.90 & 0.53 & 0.81 \\
\hline Maximum & 4.16 & 12.17 & 4.09 & 3.95 & 0.90 & 10.21 & 4.94 & 4.00 \\
\hline Mean & 1.22 & 1.04 & 1.11 & 0.87 & 0.74 & 2.58 & 1.09 & 1.26 \\
\hline $\mathrm{SD}(N=25)$ & 0.65 & 2.37 & 0.64 & 0.88 & 0.14 & 1.63 & 0.82 & 0.59 \\
\hline \multicolumn{9}{|c|}{ Fine sediments (EF with respect to UC-YC) } \\
\hline Minimum & 2.55 & 1.16 & 0.49 & 0.69 & 0.38 & 1.88 & 0.61 & 0.96 \\
\hline Maximum & 12.63 & 39.36 & 4.69 & 5.97 & 1.02 & 10.10 & 5.68 & 4.71 \\
\hline Mean & 3.72 & 3.38 & 1.27 & 1.32 & 0.84 & 2.55 & 1.26 & 1.48 \\
\hline $\operatorname{SD}(N=25)$ & 1.98 & 5.32 & 0.73 & 1.34 & 0.16 & 1.61 & 0.95 & 0.70 \\
\hline \multicolumn{9}{|c|}{ Bulk sediments (EF with respect to average shale) } \\
\hline Minimum & 0.51 & 0.40 & 0.29 & 0.37 & 0.39 & 1.77 & 0.38 & 0.43 \\
\hline Maximum & 2.45 & 7.20 & 1.17 & 4.03 & 1.44 & 6.03 & 1.13 & 1.44 \\
\hline Mean & 1.14 & 1.08 & 0.93 & 0.80 & 0.82 & 2.44 & 0.92 & 1.19 \\
\hline $\mathrm{SD}(N=25)$ & 0.34 & 1.72 & 0.20 & 0.70 & 0.21 & 0.82 & 0.17 & 0.21 \\
\hline \multicolumn{9}{|c|}{ Bulk sediments (EF with respect to UC-YC) } \\
\hline Minimum & 1.54 & 1.32 & 0.33 & 0.57 & 0.44 & 1.75 & 0.44 & 0.51 \\
\hline Maximum & 7.44 & 23.28 & 1.34 & 6.09 & 1.64 & 5.97 & 1.30 & 1.70 \\
\hline Mean & 3.47 & 3.49 & 1.07 & 1.22 & 0.93 & 2.42 & 1.06 & 1.41 \\
\hline $\mathrm{SD}(N=25)$ & 1.04 & 5.58 & 0.23 & 1.06 & 0.24 & 0.81 & 0.20 & 0.24 \\
\hline
\end{tabular}

using Varimax rotation scheme with Kaiser Normalization. Three factors were found (eigenvalues $>2$ ) to explain the $70 \%$ of the total variance $(34,25$, and $11 \%$, respectively; Table 6). Factor 1 had positive loadings for major and minor elements such as $\mathrm{Al}$, $\mathrm{Mg}, \mathrm{Na}$, and $\mathrm{P}$ along with trace elements $\mathrm{Cr}, \mathrm{Pb}, \mathrm{Ni}, \mathrm{V}$, and $\mathrm{Zn}$. Aluminum is a conservative element and a major constituent of clay minerals which is the predominant carrier phase for trace metals (Alexander et al., 1993; Selvaraj et al., 2004), and anthropogenic input of $\mathrm{Al}$ is a very rare phenomenon. Significant correlations of $\mathrm{Al}$ with $\mathrm{Mg}$ (0.81), $\mathrm{Na}$ (0.69), $\mathrm{Cr}$ (0.63), $\mathrm{Ni}$ (0.82), $\mathrm{V}(0.55)$, and $\mathrm{Zn}(0.78)$ in our sediments (Table 3 ) indicate roles of aluminosilicates in harboring these trace elements. TOC is positively correlated with some major ( $\mathrm{Al}, \mathrm{Mg}$, and $\mathrm{Na}$ ) and trace elements ( $\mathrm{Cu}$ and $\mathrm{Ni}$ ), including sand content (Table 3). Association of some of the major $(\mathrm{Al})$ and trace $(\mathrm{Cu}$ and $\mathrm{Ni}$ ) elements with TOC may suggest that $\mathrm{Cu}$ and $\mathrm{Ni}$ might also be associated with organic matter, implying that TOC in these sediments are likely in the form of coarse plant fragments that are associated with sand, as clay content has no relationship with TOC (Tables 3, 6). Low negative loadings for $\mathrm{Ca}$ and $\mathrm{CaCO}_{3}$ perhaps suggest the role of dilution by biogenic components such as carbonate on detrital components in coastal sediments. Overall, Factor 1 characterizes terrigenous input as the dominant controlling factor of sediment geochemistry in the coastal region, off the northwestern Hainan Island.

Factor 2 had positive loadings for $\mathrm{Ti}, \mathrm{Fe}, \mathrm{Mn}, \mathrm{P}$, and $\mathrm{Cd}$, the group of elements that characterizes either the influence of $\mathrm{Fe}$ Ti oxides, in particular ilmenite $\left(\mathrm{FeTiO}_{3}\right)$ or the precipitation of Fe-Mn oxyhydroxides in surface sediments along with $\mathrm{P}$ and
TABLE 6 | Varimax rotated factor matrix for surface sediments geochemical data from the Gulf of Tonkin.

\begin{tabular}{|c|c|c|c|}
\hline Variable & Factor 1 & Factor 2 & Factor 3 \\
\hline $\mathrm{Ti}$ & 0.20 & 0.97 & 0.04 \\
\hline $\mathrm{Al}$ & 0.76 & -0.59 & -0.01 \\
\hline $\mathrm{Fe}$ & 0.13 & 0.96 & 0.21 \\
\hline $\mathrm{Ca}$ & -0.51 & 0.24 & -0.36 \\
\hline $\mathrm{Mg}$ & 0.78 & -0.39 & -0.26 \\
\hline $\mathrm{Na}$ & 0.75 & -0.34 & -0.10 \\
\hline$K$ & -0.20 & -0.45 & 0.56 \\
\hline$P$ & 0.73 & 0.57 & -0.20 \\
\hline $\mathrm{Mn}$ & 0.41 & 0.87 & 0.15 \\
\hline As & 0.60 & 0.07 & 0.43 \\
\hline $\mathrm{Cd}$ & 0.02 & 0.92 & 0.21 \\
\hline $\mathrm{Cr}$ & 0.92 & 0.11 & -0.31 \\
\hline $\mathrm{Cu}$ & 0.11 & 0.00 & 0.81 \\
\hline $\mathrm{Pb}$ & 0.68 & 0.11 & 0.25 \\
\hline $\mathrm{Ni}$ & 0.84 & -0.38 & -0.13 \\
\hline V & 0.93 & 0.28 & -0.09 \\
\hline $\mathrm{Zn}$ & 0.98 & -0.05 & 0.02 \\
\hline Sand & -0.18 & -0.24 & 0.35 \\
\hline Mud & 0.13 & 0.18 & -0.29 \\
\hline TOC & 0.47 & -0.54 & 0.26 \\
\hline CaC03 & -0.32 & 0.03 & -0.41 \\
\hline Variance & 34.4 & 24.9 & 11.1 \\
\hline Eigenvalues & 7.4 & 5.3 & 2.1 \\
\hline
\end{tabular}

Cd. Based on the detailed mineral chemistry of basalts in Hainan Island, Ho et al. (2000) suggested that low pressure fractional crystallization of olivine, clinopyroxene, plagioclase and $\mathrm{Fe}-\mathrm{Ti}$ oxides from primitive magma. McLennan (2000) noted that basalt-derived sediments dominantly contain Fe- and Ti-bearing heavy minerals. In addition, the mining area of Shilu iron ore deposit is located in Changhua (Xu et al., 2013), west Hainan Island, near Changhua River, and Hainan Island is also the largest store of ilmenite in China; both may likely be responsible for the association of $\mathrm{Fe}, \mathrm{Ti}$, and $\mathrm{Cd}$ in sediments. $\mathrm{P}$ is also loaded in Factor 2 likely because it shows a great adsorption affinity with $\mathrm{Fe}-\mathrm{Mn}$ oxyhydroxides in oxic surface sediments. Negative but weak loading for TOC implies that the association in Factor 2 is largely driven by heavy minerals like ilmenite, and thus the role of TOC is less likely.

Factor 3 accounts for $11 \%$ of total variance and was positively loaded with $\mathrm{K}$, As, and $\mathrm{Cu}$, but negatively loaded with Factor 1 variables (Table 6). This association perhaps attributed to the relationship of $\mathrm{As}$ and $\mathrm{Cu}$ with potassic minerals. K-feldspar and/or clay minerals involvement on this factor seems to be likely though clay and Al both show insufficient loadings. Even though enrichment factor of $\mathrm{Pb}$ suggests a significant contribution from pollution (Table 5), this is not clearly seen from the results of factor analysis (Table 6). Lead contributes approximately $68 \%$ to Factor 1 (terrigenous input) and the remaining $25 \%$ of $\mathrm{Pb}$ is associated with $\mathrm{As}, \mathrm{Cu}$, and $\mathrm{K}$ in Factor 3 (Table 6). The association of $\mathrm{As}, \mathrm{Cu}$, and $\mathrm{Pb}$ seems to be contributed from modern sources (Figure 8), because all these trace elements show 

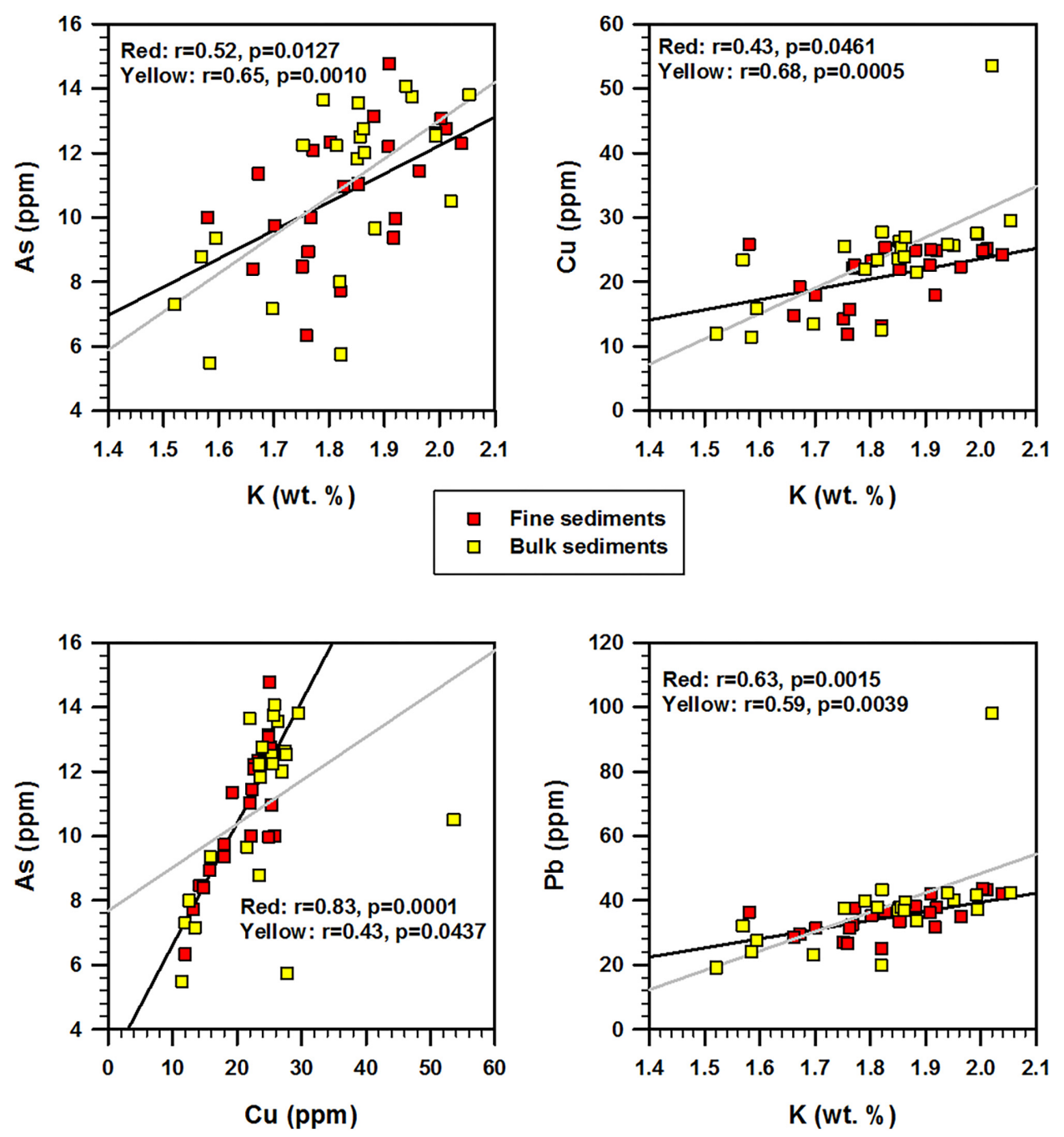

FIGURE 8 | Bi-plots of As vs. K, Cu vs. K, As vs. Cu, and Pb vs. K showing their relationships in fine and bulk fractions of surface sediments, off northwestern Hainan Island, the Gulf of Tonkin.

their maximum enrichment factors $>2$ (Table 5), implying that Factor 3 may represent modern sources for these elements in the study area (anthropogenic factor). Potassium association in this factor favors the idea that these elemental fractions from modern sources might be adsorbed on clay minerals (Figure 8), most probably on illite $-\left\{\left(\mathrm{K}, \mathrm{H}_{3} \mathrm{O}\right)(\mathrm{Al}, \mathrm{Mg}, \mathrm{Fe})_{2}(\mathrm{Si}, \mathrm{Al})_{4} \mathrm{O}_{10}\left[(\mathrm{OH})_{2}\right.\right.$, $\mathrm{H}_{2} \mathrm{O}$ ], with $\mathrm{K}$ content of $\left.6.03 \%\right\}$ - which is also one of the prominent clay minerals in the river sediments of Hainan Island (Hu et al., 2014). This inference is also corroborated with diverse contamination indices and factor analysis of seven trace elemental data in riverine bed sediments from the Hainan Island that indicated anthropogenically derived $\mathrm{Pb}$ (Zhao et al., 2015).

\section{CONCLUSION}

Although spatial analyses of major and trace elements by depth and distance from the river yields no much information, six elements ( $\mathrm{Al}, \mathrm{Fe}, \mathrm{Cr}, \mathrm{Ni}, \mathrm{V}$, and $\mathrm{Zn}$ ) spatially varied among four transects investigated in this study. Ratios of major elements to $\mathrm{Al}$ as well as the calculation of CIA and CIW suggest that the surface sediments off northwest coast of Hainan Island were derived mainly from physical erosion and/or chemical weathering of rocks (granite and basalt rocks) from the surrounding landmasses. Enrichment factors for trace metals with respect to average shale and UC$\mathrm{YC}$ reference compositions reveal higher $\mathrm{EFs}(>2)$ for $\mathrm{Pb}$, pointing that the sediments in the study area are slightly contaminated by $\mathrm{Pb}$. A comparative study of concentrations of trace elements in coastal sediments of the Gulf of Tonkin with other coastal regions of eastern China revealed that most trace metals of present study are lower than the average values reported from other coastal regions of China. We demonstrate based on trace elemental data and subsequent normalization approach that the coastal regions of Gulf of Tonkin are still in pristine environmental condition 
compared with other coastal areas in East China, although $\mathrm{Pb}$ shows slight contamination with a mean EF $>2$. Factor analysis extracts three dominant geochemical associations: (1) terrigenous input association of $\mathrm{Al}, \mathrm{Mg}, \mathrm{Na}, \mathrm{Cr}, \mathrm{Zn}, \mathrm{Ni}, \mathrm{V}$, and $\mathrm{Pb}$; (2) heavy mineral, in particular ilmenite, association of $\mathrm{Fe}$, $\mathrm{Ti}$, and $\mathrm{Cd}$; and (3) anthropogenic input of $\mathrm{As}, \mathrm{Cu}$, and $\mathrm{Pb}$. Since the preliminary study undertaken here only provides a rough idea on the environmental status in the east coast of Gulf of Tonkin, more detailed geochemical work in the Gulf of Tonkin is needed to critically evaluate the influence of basaltic contribution to and contamination tendency of sediments in the Gulf of Tonkin.

\section{DATA AVAILABILITY}

All datasets generated for this study are included in the manuscript and/or the Supplementary Files.

\section{AUTHOR CONTRIBUTIONS}

SK designed the study. DL, BL, SK, and WZ performed the field work. DL did lab work for his undergraduate thesis. J-YL carried out the grain size analysis. AZ, JZ, and XS carried out the geochemical analyses of major and trace elements. SK, BL, HW, and QL carried out the statistical analyses and all data

\section{REFERENCES}

Alexander, C. R., Smith, R. G., Calder, F. D., Schropp, S. J., and Windom, H. L. (1993). The historical record of metal enrichments in two Florida estuaries. Estuaries 16, 627-637.

Armstrong-Altrin, J. S., and Machian-Castillo, M. L. (2016). Mineralogy, geochemistry, and radiocarbon ages of deep sea sediments from the Gulf of Mexico, Mexico. J. South. Am. Earth Sci. 71, 182-200. doi: 10.1016/j.jsames. 2016.07.010

Bastami, K. D., Bagheri, H., Haghparast, S., Soltani, F., Hamzehpoor, A., and Bastami, M. D. (2012). Geochemical and geo-statistical assessment of selected heavy metals in the surface sediments of the Gorgan Bay, Iran. Mar. Pollut. Bull. 64, 2877-2884. doi: 10.1016/j.marpolbul.2012. 08.015

Bauer, A., Radziejewska, T., Liang, K., Kowalski, N., Dellwig, O., Bosselmann, K., et al. (2013). Regional differences of hydrographical and sedimentological properties in the Beibu Gulf, South China Sea. J. Coast. Res. 66, 49-71. doi: 10.2112/si_66_5

Berner, R. A. (1980). Early Diagenesis: A Theoretical Approach. Princeton, NJ: Princeton University Press, 241.

Bischoff, J. L., Piper, D. Z., and Quinterno, P. (1979). Nature and origin of metalliferous sediment in DOMES site C, pacific manganese Nodule Province. La Genese des Nodules de Manganese 289, 119-138.

Cai, S., Huang, Q., and Long, X. (2003). Three-dimensional numerical model study of the residual current in the South China Sea. Oceanol. Acta 26, 597-607. doi: 10.1016/s0399-1784(03)00053-7

Calvert, S. E., Pedersen, T. F., and Thunell, R. C. (1993). Geochemistry of the surface sediments of the Sulu and South China Seas. Mar. Geol. 114, 207-231. doi: 10.1016/0025-3227(93)90029-u

Chen, C., Li, P., Shi, M., Zou, J., Chen, M., and Sun, H. (2009). Numerical study of the tides and residual currents in the qiongzhou strait. Chin. J. Limnol. Oceanogr. 27, 931-942. doi: 10.1007/s00343-009-9193-0

Chen, C., Lu, Y., Hong, J., Ye, M., Wang, Y., and Lu, H. (2010). Metal and metalloid contaminant availability in yundong lagoon sediments, Xiamen Bay, China, interpretations. DL, SK, and $\mathrm{BL}$ wrote the manuscript with contributions from all authors.

\section{FUNDING}

This study was financially supported by the National Natural Science Foundation of China (41273083), Open Funds of the Tongji University (MGK1201), and the First Institute of Oceanography (MASEG201502 and MASEG201601), China.

\section{ACKNOWLEDGMENTS}

We appreciate the help from Zheng Liping and Xing Luru of the Institute of Deep-sea Science and Engineering, Sanya, during the sampling campaign in the Gulf of Tonkin. DL gratefully acknowledges the funding support from the Marine Science Base Project (2013C26-Research Training and Scientific Research Ability) for his undergraduate project work.

\section{SUPPLEMENTARY MATERIAL}

The Supplementary Material for this article can be found online at: https://www.frontiersin.org/articles/10.3389/fmars. 2019.00363/full\#supplementary-material

after 20 years continuous rehabilitation. J. Hazard. Mater. 175, 1048-1055. doi: 10.1016/j.jhazmat.2009.10.117

Chen, C. T. A., and Selvaraj, K. (2008). Evaluation of elemental enrichments in surface sediments off southwestern Taiwan. Environ. Geol. 54, 1333-1346. doi: 10.1007/s00254-007-0916-2

Coleman, J. M. (1969). Brahmaputra river: channel processes and sedimentation. Sediment. Geol. 3, 129-239. doi: 10.1016/0037-0738(69)90010-4

Dou, Y., Li, J., Zhao, J., Hu, B., and Yang, S. (2013). Distribution, enrichment and source of heavy metals in surface sediments of the eastern Beibu Bay, South China Sea. Mar. Pollut. Bull. 67, 137-145. doi: 10.1016/j.marpolbul.2012.11.022

Fedo, C. M., Eriksson, K. A., and Krogstad, E. J. (1996). Geochemistry of shales from the Archean $(\sim 3.0 \mathrm{Ga})$ buhwa greenstone belt, Zimbabwe: implications for provenance and source-area weathering. Geochim. Cosmochim. Acta 60, 1751-1763. doi: 10.1016/0016-7037(96)00058-0

Fyhn, M. B. W., Thomsen, T. B., Keulen, N., Knudsen, C., Rizzi, M., BojesenKoefoed, J., et al. (2019). Detrital zircon ages and heavy mineral composition along the Gulf of Tonkin - implications for sand provenance in the yinggehaisong hong and qiongdongnan basins. Mar. Petrol. Geol. 101, 162-179. doi: 10.1016/j.marpetgeo.2018.11.051

Förstner, U., and Wittmann, G. T. W. (1981). Metal Pollution in the Aquatic Environment. Berlin: Springer.

Gan, H., Lin, J., Liang, K., and Xia, Z. (2013). Selected trace metals (As, Cd and $\mathrm{Hg}$ ) distribution and contamination in the coastal wetland sediment of the northern Beibu Gulf, South China Sea. Mar. Pollut. Bull. 66, 252-258. doi: 10.1016/j.marpolbul.2012.09.020

Gan, J., Jia, X., Li, C., Cai, W., Wang, Z., and Wu, Q. (2003). Characteristics of distribution and pollution of heavy metals in surfacial sediments from the continental shelf of Northern South China Sea. J. Trop. Oceanogr. 22, 36-42.

Gao, J., Wu, G., and Ya, H. (2017). Review of the circulation in the beibu gulf, South China Sea. Cont. Shelf Res. 138, 106-119. doi: 10.1016/j.csr.2017.02.009

Gao, S., Luo, T. C., Zhang, B. R., Zhang, H. F., Han, Y. W., Zhao, Z. D., et al. (1998). Chemical composition of the continental crust as revealed by studies in East China. Geochim. Cosmochim. Acta 62, 1959-1975. doi: 10.1016/s0016-7037(98) 00121-5 
Grimalt, J. O., Elbaz-Poulichet, F., and Lipiatou, E. (2001). Still worrying with trace chemical pollution. Mar. Pollut. Bull. 42, 621-622. doi: 10.1016/s0025-326x(01) 00081-9

Gromet, L. P., Haskin, L. A., Korotev, R. L., and Dymek, R. F. (1984). The "North American shale composite": its compilation, major and trace element characteristics. Geochim. Cosmochim. Acta 48, 2469-2482. doi: 10.1016/00167037(84)90298-9

Harnois, L. (1988). The CIW index: a new chemical index of weathering. Sediment. Geol. 55, 319-322. doi: 10.1016/0037-0738(88)90137-6

Ho, K. S., Chen, J. C., and Juang, W. S. (2000). Geochronology and geochemistry of late cenozoic basalts from the leiqiong area, southern China. J. Asian Earth Sci. 18, 307-324. doi: 10.1016/s1367-9120(99)00059-0

Hu, B., Li, J., Cui, R., Wei, H., Zhao, J., Li, G., et al. (2014). Clay mineralogy of the riverine sediments of Hainan Island, South China Sea: implications for weathering and provenance. J. Asian Earth Sci. 96, 84-92. doi: 10.1016/j.jseaes. 2014.08.036

Janitzky, P. (1986). "Particle size analysis," in Field and Laboratory Procedures Used in Soil Chronosequence Study, eds M. J. Singer and P. Janitzky (Washington, DC: United States Government ublishing Office).

Jiang, K., Qi, H. -W., and Hu, R. -Z. (2018). Element mobilization and redistribution under extreme tropical weathering of basalts from the Hainan Island, South China. J. Asian Earth Sci. 18, 80-102. doi: 10.1016/j.jseaes.2018. 02.008

Jin, L., Chu, F. Y., Zhao, J. R., and Zhai, W. L. (2011). An evaluation on heavy metal contamination in the surface sediments of northwestern part of South China Sea. J. Mar. Sci. 29, 24-34.

Koschinsky, A., Stascheit, A., Bau, M., and Halbach, P. (1997). Effects of phosphatization on the geochemical and mineralogical composition of marine ferromanganese crusts. Geochim. Cosmochim. Acta 61, 4079-4094. doi: 10.1016/s0016-7037(97)00231-7

Krumgalz, B. S., Fainshtein, G., and Cohen, A. (1992). Grain size effect on anthropogenic trace metal and organic matter distribution in marine sediments. Sci. Total Environ. 116, 15-30. doi: 10.1016/0048-9697(92)90362-v

Li, L. (1992). Hydrological character in Hainan Island. Hydrology 6, 49-51.

Lian, X. (2002). The assessment on the pollution of heavy metals in sediment of Guangxi inshore. Mar. Environ. Sci. 21, 39-42.

Liu, Z. F., Wang, H., Hantoro, W. S., Sathiamurthy, E., Colin, C., Zhao, Y. L., et al. (2012). Climatic and tectonic controls on chemical weathering in tropical Southeast Asia (Malay Peninsula, Borneo, and Sumatra). Chem. Geol. 291, 1-12. doi: 10.1016/j.chemgeo.2011.11.015

Loring, D. H. (1991). Normalization of heavy-metal data from estuarine and coastal sediments. ICES J. Mar. Sci. 48, 101-115. doi: 10.1093/icesjms/48.1.101

Loring, D. H., and Rantala, R. T. T. (1992). Manual for the geochemical analyses of marine sediments and suspended particulate matter. Earth Sci. Rev. 32, 235-283. doi: 10.1016/0012-8252(92)90001-a

Manh, D. -V., and Yanagi, T. (1997). A three-dimensional numerical mode of tide and tidal current in the Gulf of Tonkin. La Mer 35, 15-22.

Manh, D. - V., and Yanagi, T. (2000). A study on residual flow in the Gulf of Tonkin. J. Oceanogr. 56, 59-68.

McLennan, S. M. (2000). Chemical composition of martian soil and rocks: complex mixing and sedimentary transport. Geophys. Res. Lett. 27, 1335-1338. doi: 10.1029/1999gl008432

Meng, F., Wang, Z., Cheng, F., Du, X., Fu, W., Wang, Q., et al. (2013). The assessment of environmental pollution along the coast of Beibu Gulf, northern South China Sea: an integrated biomarker approach in the clam meretrix meretrix. Mar. Environ. Res. 85, 64-75. doi: 10.1016/j.marenvres.2013. 01.003

Meybeck, M., Laroche, L., Dürr, H. H., and Syvitski, J. P. M. (2003). Global variability of daily total suspended solids and their fluxes in rivers. Glob. Planet. Change 39, 65-93. doi: 10.1016/s0921-8181(03)00018-3

Milliman, J. D., and Syvitski, J. P. M. (1992). Geomorphic/tectonic control of sediment discharge to the ocean: the importance of small mountainous rivers. J. Geol. 100, 525-544. doi: 10.1086/629606

Nath, B. N., Kunzendorf, H., and Pluger, W. L. (2000). Influence of provenance, weathering, and sedimentary processes on the elemental ratios of the finegrained fraction of the bedload sediments from the Vembanad Lake and the adjoining continental shelf, southwest coast of India. J. Sediment. Res. 70, 1081-1094. doi: 10.1306/100899701081
Nath, B. N., Rao, V. P., and Becker, K. P. (1989). Geochemical evidence of terrigenous influence in deep-sea sediments up to $8^{\circ} \mathrm{S}$ in the Central Indian Basin. Mar. Geol. 87, 301-313. doi: 10.1016/0025-3227(89)90067-4

NBO (2009). National Bureau of Oceanography of China. Bull. Mar. Environ. Qual. 2008-2009.

Nesbitt, H. W., and Markovics, G. (1980). Chemical processes affecting alkalis and alkaline earths during continental weathering. Geochim. Cosmochim. Acta 44, 1659-1666. doi: 10.1016/0016-7037(80)90218-5

Nesbitt, H. W., and Young, G. M. (1982). Early Proterozoic climates and plate motions inferred from major element chemistry of lutites. Nature 299, 715-717. doi: 10.1038/299715a0

Nesbitt, H. W., Young, G. M., McLennan, S. M., and Keays, R. R. (1996). Effects of chemical weathering and sorting on the petrogenesis of siliciclastic sediments, with implications for provenance studies. J. Geol. 104, 525-542. doi: 10.1086/ 629850

Nolting, R. F., Ramkema, A., and Everaarts, J. M. (1999). The geochemistry of $\mathrm{Cu}, \mathrm{Cd}, \mathrm{Zn}, \mathrm{Ni}$ and $\mathrm{Pb}$ in sediment cores from the continental slope of the Banc d'Arguin (Mauritania). Cont. Shelf Res. 19, 665-691. doi: 10.1016/s02784343(98)00109-5

Nriagu, J. O., and Pacyna, J. M. (1988). Quantitative assessment of worldwide contamination of air, water and soils by trace metals. Nature 333, 134-139. doi: $10.1038 / 333134 \mathrm{a} 0$

Pan, K., and Wang, W. X. (2012). Trace metal contamination in estuarine and coastal environments in China. Sci. Total Environ. 421-422, 3-16. doi: 10.1016/ j.scitotenv.2011.03.013

Rainbow, P. S. (2007). Trace metal bioaccumulation: models, metabolic availability and toxicity. Environ. Int. 33, 576-582. doi: 10.1016/j.envint.2006.05.007

Salomons, W., and Förstner, U. (1980). Trace metal analysis on polluted sediments: part II: evaluation of environmental impact. Environ. Technol. 1, 506-517. doi: 10.1080/09593338009384007

Selvaraj, K., and Chen, C. T. A. (2006). Moderate chemical weathering of subtropical Taiwan: constraints from solid-phase geochemistry of sediments and sedimentary rocks. J. Geol. 114, 101-116. doi: 10.1086/498102

Selvaraj, K., Lin, B. Z., Lou, J. Y., Xia, W. L., Huang, X. T., and Chen, C. T. A. (2016). Lacustrine sedimentological and geochemical records for the last 170 years of climate and environmental changes in southeastern China. Boreas 45 , 165-179. doi: 10.1111/bor.12143

Selvaraj, K., Parthiban, G., Chen, C. T. A., and Lou, J. Y. (2010). Anthropogenic effects on sediment quality offshore southwestern Taiwan: assessing the sediment core geochemical record. Cont. Shelf Res. 30, 1200-1210. doi: 10.1016/ j.csr.2010.03.010

Selvaraj, K., Ram Mohan, V., and Szefer, P. (2004). Evaluation of metal contamination in coastal sediments of the Bay of Bengal, India: geochemical and statistical approaches. Mar. Pollut. Bull. 49, 174-185. doi: 10.1016/j. marpolbul.2004.02.006

Shi, M., Chen, C., Xu, O., Lin, H., Liu, G., Wang, H., et al. (2002). The role of qiongzhou strait in the seasonal variation of the South China Sea circulation. J. Phys. Oceanogr. 32, 103-121. doi: 10.1175/1520-0485(2002) 032<0103:troqsi 2.0. co; 2

Shi, X., Kohn, B., Spencer, S., Guo, X., Li, Y., Yang, X., et al. (2011). Cenozoic denudation history of southern Hainan Island, South China Sea: constraints from low temperature thermochronology. Tectonophysics 504, 100-115. doi: $10.1016 /$ j.tecto.2011.03.007

Song, J. (2009). Estimate the rationality of spatial structure of Beibu Gulf (Guangxi) economic zone and analyze the agglomeration trend. Int. J. Bus. Manage 4, $132-137$.

Su, G. O., and Wang, T. X. (1994). "Basic characteristics of modern sedimentation in the South China Sea," in Oceanology of China Seas, Vol. 2, eds D. Zhou, Y. B. Liang, and C. K. Zeng (Dordrecht: Kluwer), 407-418. doi: 10.1007/978-94-0110862-1_39

Sundelin, B., and Eriksson, A. K. (2001). Mobility and bioavailability of trace metals in sulfidic coastal sediments. Environ. Toxicol. Chem. 20, 748-756. doi: $10.1002 /$ etc. 5620200408

Syvitski, J. P. M., and Milliman, J. D. (2007). Geology, geography, and humans battle for dominance over the delivery of fluvial sediment to the coastal ocean. J. Geol. 115, 1-19. doi: 10.1086/509246

Szefer, P. (2002). Metals, Metalloids and Radionuclides in the Baltic Sea Ecosystem, Vol. 5. Amsterdam: Elsevier, 764. 
Szefer, P., Glasby, G. P., Pempkowiak, J., and Kaliszan, R. (1995). Extraction studies of heavy-metal pollutants in surficial sediments from the southern Baltic Sea off Poland. Chem. Geol. 120, 111-126. doi: 10.1016/0009-2541(94)00103-f

Szefer, P., Glasby, G. P., Stüben, D., Kusak, A., Geldon, J., Berner, Z., et al. (1999). Distribution of selected heavy metals and rare earth elements in surficial sediments from the Polish sector of the Vistula Lagoon. Chemosphere 39, 2785-2798. doi: 10.1016/s0045-6535(99)00208-8

Tanabe, S., Hori, K., Saito, Y., Haruyama, S., Doanh, L. Q., Sato, Y., et al. (2003). Sedimentary facies and radiocarbon dates of the Nam Dinh-1 core from the Song Hong (Red River) delta Vietnam. J. Asian Earth Sci. 21, 503-513. doi: 10.1016/s1367-9120(02)00082-2

Tang, D., Kawamura, H., Lee, M. A., and Van Dien, T. (2003). Seasonal and spatial distribution of chlorophyll-a concentrations and water conditions in the Gulf of Tonkin, South China Sea. Remote Sens. Environ. 85, 475-483. doi: 10.1016/s0034-4257(03)00049-x

Taylor, S. R., and McLennan, S. M. (1985). The Continental Crust: Its Composition and Evolution. Oxford: Blackwell Scientific Publications, 312.

Turekian, K. K., and Wedepohl, K. H. (1961). Distribution of the elements in some major units of the Earth's crust. Geol. Soc. Am. Bull. 72, 175-192.

Wang, C., Cui, L., and Wang, D. (2015). Distribution and pollution assessment of heavy metals in surface sediments of aquaculture area in Yueqing Bay. Trans. Chin. Soc. Agric. Eng. 31, 204-210.

Windom, H. L., Schropp, S. J., Calder, F. D., Ryan, J. D., Smith, R. G. Jr., Burney, L. C., et al. (1989). Natural trace metal concentrations in estuarine and coastal marine sediments of the southeastern United States. Environ. Sci. Technol. 23, 314-320. doi: 10.1021/es00180a008

Winters, G. V., and Buckley, D. E. (1992). Factor analysis as a method of evaluation sediment environmental quality in Halifax Harbour, Nova Scotia. Curr. Res. D Geol. Surv. Can. Pap. 92-1D, 165-171.

Wu, D., Wang, Y., Lin, X., and Yang, J. (2008). On the mechanism of the cyclonic circulation in the Gulf of Tonkin in the summer. J. Geophys. Res. 113:C09029. doi: 10.1029/2007JC004208

Wu, Y., Wu, S., and Zhai, P. (2007). The impact of tropical cycles on Hainan Island's extreme and total precipitation. Int. J. Climatol. 27, 1059-1064. doi: 10.1002/joc. 1464

Xia, P., Meng, X., Feng, A., Yin, P., Zhang, J., and Wang, X. (2012). Geochemical characteristics of heavy metals in coastal sediments from the northern Beibu Gulf (SW China): the background levels and recent contamination. Environ. Earth Sci. 66, 1337-1344. doi: 10.1007/s12665-011-1343-y

Xia, P., Meng, X., Yin, P., Cao, Z., and Wang, X. (2011). Eighty-years sedimentary record of heavy metal inputs in the intertidal sediments from the Nanliu River estuary, Beibu Gulf of South China Sea. Environ. Pollut. 159, 92-99. doi: 10.1016/j.envpol.2010.09.014

Xia, P., Meng, X. W., Yin, P., and Liu, L. J. (2008). Heavy metal pollution and its potential ecological risk in the sediments from the Beihai Intertidal Zone of Guangxi Province. Adv. Mar. Sci. 26, 471-477.

Xia, Z., Waniek, J. J., and Leipe, T. (2013). Anthropogenic fingerprint in Beibu Gulf (South China Sea) sediments. J. Coast. Res. 66, 72-90. doi: 10.2112/si_66_6

$\mathrm{Xu}, \mathrm{D}$. , Long, J., Qian, J., and Xi, P. (2008). The modern sedimentation rate and the distribution character of 7 cores in Hainan Island off shore. J. Mar. Sci. 26, 9-17.
Xu, D., Wang, Z. L., Cai, J. X., Wu, C. J., Bakun-Czubarow, N., Wang, L., et al. (2013). Geological characteristics and metallogenesis of the Shilu Fe-ore deposit in Hainan Provenance, South China. Ore Geol. Rev. 53, 318-342. doi: 10.1016/ j.oregeorev.2013.01.015

Xu, Y., Sun, Q., Cai, G., Yin, X., and Chen, J. (2014). The U-Pb ages and Hf isotopes of detrital zircons from Hainan Island, South China: implications for sediment provenance and the crustal evolution. Environ. Earth Sci. 71, 1619-1628. doi: 10.1007/s12665-013-2566-x

Yang, C. L., Ouyang, T., Zhang, L. P., Jing, Y. H., Ye, X., Yu, X. T., et al. (2007). Speciation of heavy metals in surface sediments from Xiamen Western Harbor. J. Xiamen Univ. 46, 89-93.

Yang, Z., Jia, J., Wang, X., and Gao, J. (2013). Characteristics and variations of water and sediment fluxes into the sea of the top three rivers of Hainan in recent 50 years. Mar. Sci. Bull. 32, 92-99.

Yu, R., Yuan, X., Zhao, Y., Hu, G., and Tu, X. (2008). Heavy metal pollution in intertidal sediments from Quanzhou Bay, China. J. Environ. Sci. 20, 664-669. doi: 10.1016/s1001-0742(08)62110-5

Zhang, J., Wang, D. R., Jennerjahn, T., and Dsikowitzky, L. (2013). Land-sea interactions at the east coast of Hainan Island, South China Sea: a synthesis. Cont. Shelf Res. 57, 132-142. doi: 10.1016/j.csr.2013.01.004

Zhang, Y. H., and Du, J. M. (2005). Background values of pollutants in sediments of the South China Sea. Acta Oceanol. Sin. 27, 161-166.

Zhao, D., Wan, S., Yu, Z., and Huang, J. (2015). Distribution, enrichment and sources of heavy metals in surface sediments of Hainan Island rivers, China. Environ. Earth Sci. 74, 5097-5110. doi: 10.1007/s12665-015-4522-4

Zhou, X., Li, Y., Wang, E., and Liu, X. (2004). Heavy metals pollution and relevant ecological risk evaluation in wetlands of Liaodong Gulf area. Environ. Sci. Technol. Chem. 27, 60-62.

Zou, J. J., Shi, X. F., Liu, Y. G., Selvaraj, K., and Kao, S. J. (2012). Reconstruction of environmental changes using a multi-proxy approach in the Ulleung Basin (Sea of Japan) over the last 48 ka. J. Q. Sci. 27, 891-900. doi: 10.1002/jqs. 2578

Zuo, P. W. Y., Min, F. Y., and Cheng, J. (2009). Distribution characteristics of heavy metals in surface sediments and core sediments of the Shenzhen Bay in Guangdong Province, China. Acta Oceanol. Sin. 28, 53-60.

Zwolsman, J. J. G., van Eck, G. T. M., and Burger, G. (1996). Spatial and temporal distribution of trace metals in sediments from the Scheldt estuary, southwest Netherlands. Estuar. Coast. Shelf Sci. 43, 55-79. doi: 10.1006/ecss. 1996. 0057

Conflict of Interest Statement: The authors declare that the research was conducted in the absence of any commercial or financial relationships that could be construed as a potential conflict of interest.

Copyright (c) 2019 Liu, Lin, Kandasamy, Wang, Liu, Zou, Zhu, Zou, Lou and Shi. This is an open-access article distributed under the terms of the Creative Commons Attribution License (CC BY). The use, distribution or reproduction in other forums is permitted, provided the original author(s) and the copyright owner(s) are credited and that the original publication in this journal is cited, in accordance with accepted academic practice. No use, distribution or reproduction is permitted which does not comply with these terms. 